\title{
Estética da imperfeição: o pensamento de John Ruskin e a arquitetura rural em Santa Catarina
}

A esthetic of imperfection: the thought of John Ruskin and the rural architecture in Santa Catarina

http://dx.doi.org/10.1590/1982-02672019v27e23

\section{ELIANE BAADER DE LIMA'}

https://orcid.org/0000-0002-2030-1914

Universidade Federal de Santa Catarina / Florianópolis, SC, Brasil

\section{RODRIGO ALMEIDA BASTOS 2}

https: / / orcid.org/0000-0002-6050-6279

Universidade Federal de Santa Catarina / Florianópolis, SC, Brasil

RESUMO: $O$ presente artigo apresenta uma proposta de perceber a arquitetura rural edificada pelo artífice imigrante em Santa Catarina a partir do pensamento estético de John Ruskin. As concepç̃̃es que formam o seu pensamento são tomadas à luz do conceito do fantástico paradoxo, uma chave de leitura bastante oportuna para evidenciar e reiterar características fundamentais daquela arquitetura, como a presença viva do labor humano, a imperfeição como virtude construtiva e a beleza pitoresca da paisagem edificada. A partir da análise de um conjunto arquitetônico construído em madeira, buscou-se compreender a presença do artífice construtor tanto no corpo mesmo do edifício resguardado em sucessivas gerações quanto na preservação de um saber-fazer de técnicas construtivas tradicionais transmitidas de pai para filho.

PALAVRAS-CHAVES: John Ruskin. Arquitetura. Artífice. Imperfeição.

ABSTRACT: This article presents a proposal to perceive the rural architecture built by the immigrant artisans in Santa Catarina, from the aesthetic thinking of John Ruskin. The conceptions that form his thinking are taken in light of the concept of the fantastic paradox, a key of reading quite opportune to highlight and reiterate fundamental characteristics of that architecture, such as: the
1. Mestre em Arquitetura e Urbanismo pela Universidade Federal de Santa Catarina (UFSC). E-mail: <elianebaader@ gmail.com>

2. Arquiteto urbanista e engenheiro civil. Mestre em Arquitetura e Urbanismo pela Universidade Federal de Minas Gerais (UFMG) e doutor em Arquitetura e Urbanismo pela Universidade de São Paulo (USP), com doutoradosanduíche no Departamento de História da Arte da Universidade Nova de Lisboa e pós-doutorado pela McGill University, Montreal, Canadá. Atualmente é professor do Departamento de Arquitetura e Urbanismo da UFSC. E-mail: $<$ rodrigobastos.arq@gmail. com> 
living presence of human labor, imperfection as constructive virtue and picturesque beauty of the built landscape. From the analysis of an architectural set built in wood, we sought to understand the presence of the builder in both the body of the building sheltered in successive generations, and in the preservation of a know-how of traditional constructive techniques transmitted from father to son.

KEYWORDS: John Ruskin. Architecture. Craftsman. Imperfection. 
O debate intelectual que se desenvolveu no século XIX a respeito das práticas artísticas foi marcado por vários e intensos questionamentos. Dois dos mais significativos implicavam aspectos essenciais: a discussão sobre a natureza da arte e também a sua relação com a sociedade industrial que crescia e se consolidava rapidamente. Na Inglaterra vitoriana, John Ruskin (1819-1900), que já havia começado seus importantes escritos críticos sobre a arte, manifestados no primeiro volume de Pintores Modernos, publicava, em 1849, As Sete Lâmpadas da Arquitetura, anunciando suas reflexões sobre a prática artística no fazer arquitetônico. Já na publicação seguinte, nos três volumes de As Pedras de Veneza, elaborados entre 1851 e 1853, Ruskin tornava ainda mais evidente o impulso que parece alimentar toda a sua intenção crítica: reaproximar a arte da vida e restabelecer o prazer humano no trabalho artístico. A partir daí, o pensamento ruskiniano concentra-se numa apaixonada crítica ao declínio do trabalho expressivo na sociedade moderna e industrial, principalmente aquele realizado pelo homem comum. Isso o fez também se aproximar das questões sociais, sobre as quais o autor se dedicaria mais adiante, em seus escritos sobre a economia política da arte. ${ }^{3}$ As publicações sobre a economia política da arte representariam o posicionamento do autor sobre os problemas sociais e as mazelas do século XIX, provocados, principalmente, pela industrialização. ${ }^{4}$ Dentre as diversas reflexões que se desenvolveram ao longo dos oitocentos sobre a estética industrial, as questões levantadas por Ruskin em relação às práticas artísticas o tornaram um dos pensadores mais importantes desse período, tanto para a teoria da arte quanto para a história mesma da arquitetura. Para além dos questionamentos acerca da aparência e da falta de qualidade artística dos produtos oriundos da produção seriada e fabril, Ruskin reclamava pela presença viva do trabalhador na fatura de seu ofício, algo que só poderia ser alcançado, segundo ele, pela justa comunhão entre trabalho e pensamento e pelo prazer que tal comunhão despertaria no operário. A vida manifestada no gesto animado do trabalhador é o que conferia, então, valor à coisa produzida. Numa crítica declarada à moderna manufatura do século XIX, Ruskin proclamava que a verdadeira riqueza e prosperidade de uma nação não dependeria da quantidade de mercadoria fabricada, mas, outrossim, da quantidade de vida produzida por meio do seu trabalho.

Recuperar a capacidade do trabalhador e trazer de volta a pulsão de vida ao labor expressivo do homem comum são duas das grandes reivindicações presentes no discurso ruskiniano, se considerarmos os textos publicados sobre arquitetura e parte das publicações feitas sobre a economia política da arte.
3. A expressão "economia política da arte" refere-se aqui ao momento em que o pensamento e os escritos de Ruskin se voltaram para as questões sociais. Para Cardoso, seria por volta de 1853 que Ruskin teria começado a refletir sobre a função social da arte e teria passado a "privilegiar as grandes questões sociais de sua época". Cardoso. In: Ruskin (2004, prefácio, p. 10). Cf. Clark (1950; 1967), Landow (1971), Townsend (1951) e Cook. Ruskin (1905, introdução), no momento em que se dedica aos textos sobre a economia política da arte, principalmente em A Joy for ever e em Unto this Last, parece haver em seu pensamento uma consolidação em relação às questões sociais de seu tempo. De acordo com Townsend, se no primeiro volume de Pintores Modernos, a arte era, para Ruskin, a salvação da humanidade, no terceiro volume de As Pedras de Veneza, a arte só poderia ser produzida por uma sociedade saudável econômica, política e moralmente. Townsend (1951, p. 69). Vale ressaltar que, em seu pensamento estético-moral, Ruskin faz uma relação entre a decadência das práticas artísticas e a corrupção das relações sociais, morais e econômicas de seu tempo. Ao tecer tal pensamento, Ruskin o faz perpassando vários temas - como pintura, arquitetura e economia política -, e isso, de certa forma, os aproximam e os tornam vinculados. Dessa forma, suas considerações sobre pintura alimentam suas ideias sobre arquitetura, e suas considerações sobre o trabalho na arquitetura animam suas reflexões sobre a economia política.

4. Esta compreensão é observada por Clark (1950; 1967), Landow (1971), 
Townsend (1951) e Cook. In: Ruskin (1905, introdução).

5. E. T. Cook e Alexander Wedderburn são os editores da compilação Works, que reúne as publicações de John Ruskin em 39 volumes, disponibilizada pela Lancaster University/Ruskin Library. Parte dessa compilação foi utilizada para compor a dissertação de mestrado - $O$ fantástico paradoxo no pensamento estético de John Ruskin e a presença do artífice na arquitetura rural de Santa Catarina - da qual este texto resulta. Segundo Cook, já no final do segundo volume de Pintores Modernos, Ruskin teria começado a dedicar-se aos estudos sobre arquitetura, sobretudo à arquitetura gótica, e a obra As Sete Lâmpadas da Arquitetura guardaria o embrião dos futuros estudos em relação à economia política da arte. Já em As Pedras de Veneza, Ruskin teria se debruçado sobre o cerne da questão, ao declarar a indissociável relação entre o temperamento moral do homem e suas práticas artísticas. Cook. In: Ruskin (1903, introdução).

6. Ruskin (1904, v.II, p. 204, tradução nossa). No original: "Accept this then for a universal law, that neither architecture nor any other noble work of man can be good unless it be imperfect."

7. A expressão "fantástico paradoxo" foi utilizada por Ruskin em seu conhecido texto A natureza do gótico, ao encerrar a definição de "savageness" - o primeiro dos elementos que constitui a natureza de sua arquitetura. Nele, o autor afirmava que tanto a imperfeição humana seria formadora do caráter da beleza na arquitetura quanto a exigência da perfeição teria sido a primeira causa
Segundo Cook, ${ }^{5}$ Ruskin teria sido um dos primeiros a questionar o prazer que o trabalho de execução na arquitetura proporcionava ou deveria proporcionar ao trabalhador que o realizava. Isso significou um questionamento das relações entre trabalho, vida e moralidade nas práticas artísticas, sobretudo na arquitetura. Para o autor, esta representava a expressão do temperamento moral tanto daqueles que a fizeram como daqueles para quem havia sido produzida. A escolha de um estilo ou de uma "escola" de arquitetura representaria, então, mais que o resultado de uma seleção formal; ela seria o cerne mesmo de uma escolha a influenciar, pelo caráter, a vida de trabalhadores e de comitentes. Na estética ruskiniana, a beleza das formas externas, especialmente na arquitetura, dependeria dessa felicidade advinda do ofício laboral.

Suas investigações sobre o trabalho na arquitetura, desde as práticas dos artesãos góticos até a produção industrial de seu tempo, alicerçam a sua crítica em relação à perfeição, um dos preceitos mais recorrentes da arte de ascendência dita clássica. Em seus escritos sobre a natureza da arquitetura gótica, ao tentar definir os elementos que formam a sua "expressão mental" e que constituem a sua condição moral, Ruskin declarava que "nem a arquitetura, nem qualquer outro trabalho do homem poderiam ser verdadeiramente nobres se não fossem imperfeitos". " Da mesma maneira, os elementos que dariam corpo à sua materialidade e que caracterizariam a sua "expressão formal" também deveriam ser orientados pelo princípio da imperfeição. $\bigcirc$ "fantástico paradoxo", , proposto pelo autor, talvez tenha sido uma das maiores contribuições do pensamento crítico ruskiniano, na contramão de toda doutrina mimética vigente da Antiguidade até o século XVIII. Ao reconhecer a imperfeição como característica da própria natureza humana, Ruskin colocava outra forma de compreender a beleza, para além da perfeição formal e da beleza visual das proporções justas, decorosas e corretas. Para o olhar ruskiniano, a imperfeição e as limitações humanas eram fundamentais na formação do caráter da beleza, na arquitetura mormente.

Manifestada somente por meio de uma certa liberdade de pensamento, essa imperfeição estaria diretamente ligada ao trabalho humano no fazer arquitetônico. A presença do trabalho humano como gesto vivo, particularmente aquele realizado pelo trabalhador comum na arquitetura, deveria ser alimentada por essa energia vital. E o gesto animado dos trabalhadores que ajudaram a erguer a edificação deixaria, no corpo mesmo daquela matéria, as marcas e os vestígios de tal presença humana. Entretanto, se tais imperfeições positivas estivessem diretamente ligadas ao gesto vivo do trabalhador, tal gesto somente poderia ser animado pela comunhão entre trabalho e pensamento. Essa comunhão se manifestaria na prática oficial do trabalhador, principalmente, por duas formas de 
expressão: pela fantasia que alimenta a alma e o pensamento - o que o levaria ao que o autor chama de "fantasia grotesca" (grotesqueness) ${ }^{8}$ - e pelas limitações que constituem o próprio fazer humano - o que o levaria a uma "rudeza de expressão". Assim, o fantástico paradoxo revelar-se-ia, sobretudo, na aceitação da natureza humana - inventiva e criadora, embora mortal e, por vezes, errante como condição primeira na fatura de qualquer ação do homem. Sua manifestação seria a expressão mesma, imperfeita, testemunhal, da comunhão entre trabalho e pensamento, da comunhão entre matéria e espírito.

Contudo, ao questionar o prazer que deveria estar presente na fatura do trabalho expressivo do homem e ao criticar a falta de valorização da vida no trabalho, especialmente na arquitetura, Ruskin acabava por entrar numa discussão direta com a moralidade ou a imoralidade do sistema produtivo vigente. A "grande invenção civilizada da divisão do trabalho", ao fracionar a atividade humana numa linha de produção, acabava por fracionar também o próprio homem. Fragmentado em "migalhas de vida", a menor porção de sua "inteligência remanescente" não seria suficiente, segundo ele, para que fizesse sequer "um alfinete ou um prego". 9 Para o autor, existiriam determinados trabalhos que precisariam ser feitos para 0 nosso pão e estes deveriam ser feitos arduamente. Entretanto, existiriam outros trabalhos que seriam feitos para o nosso prazer, e estes deveriam ser feitos calorosamente. Mas nenhum dos dois deveria ser realizado pela metade ou em partes. Se a divisão do trabalho era prejudicial ao trabalho comum, ela seria inadmissível às artes e às suas diversas naturezas, sobretudo porque, segundo ele, a materialidade de um trabalho fragmentado e sem vida, embora pudesse nos emocionar pela aparência de suas formas e de seus acabamentos, seria nula em vitalidade, em energia, em moralidade. A crítica de Ruskin também se voltava para as distorções que o processo fabril e capitalista poderia produzir ou já estaria produzindo na condição humana, corrompendo principalmente a percepção, a sensibilidade, a moralidade e a ética. ${ }^{10}$

Cabe ressaltar que a manifestação artística, assim como a aplicação das diferentes naturezas da arte, eram, para Ruskin, um trabalho, um ofício ligado ao saber-fazer do homem comum, artista ou artífice. E, como todo trabalho produzido pelo homem, o trabalho artístico também carregaria o testemunho de sua moralidade. Desse modo, o objeto estético deveria ser igualmente um objeto éticomoral, uma vez que a matéria produzida pelo homem estaria completamente vinculada ao espírito que o alimenta. Da mesma forma, o trabalho artístico também carregaria o testemunho de vida e de prazer presentes em sua execução. A arteofício ${ }^{11}$ deveria, então, estar ordenada em dois postulados principais: ser um exercício artístico-moral e manifestar, por meio de sua materialidade, o prazer $^{12}$ do declínio das práticas artísticas na Europa. Ruskin (1904, v. II, p. 204). As expressões "fantástico paradoxo" e "fantástico paradoxo da imperfeição", utilizadas ao longo deste artigo, mantêm relação direta com a ideia central proposta pelo autor.

8. O termo grotesqueness é um dos seis elementos elencados por Ruskin que caracterizam a natureza da arquitetura gótica. Ao compor a definição de grotesque, manifestada pela imaginação do homem, Ruskin sugeria a humanidade dividida em quatro classes, considerando o seu maior ou menor grau de ludicidade (playfulness): aqueles que brincam (play) com sabedoria, aqueles que brincam por necessidade, aqueles que brincam desordenadamente e aqueles que não brincam. Para Ruskin, uma sociedade equilibrada em suas relações de trabalho deveria ser formada apenas pelas duas primeiras classes. Ruskin (1904, v. III, p. 135-195).

9. Ruskin (1904, v. II, p. 196, tradução nossa). No original: "Divided into mere segments of men-broken into small fragments and crumbs of life; so that all the little piece of intelligence that is left in a man is not enough to make a pin, or a nail, but exhausts itself in making the point of a pin or the bead of a nail."

10. Esta compreensão é observada por Cook. In: Ruskin (1904; 1905 introdução); Clark (1950; 1967); Townsend (1951); Frampton (2015) e Lira (2006).

11. A expressão arte-ofício compreende tanto o objeto estético quanto o objeto artístico porque ambos, no pensamento ruskiniano, são o resultado do trabalho expressivo do homem, 
embora de naturezas distintas. A diferença entre arte e arte decorativa estaria ligada à sua constituição, à sua natureza e à sua aplicação. Enquanto a arte seria aquela de "vontade i n d e p e nd e n t e", insubordinável, e que alcançaria a completude em si mesma, a arte decorativa estaria subordinada ao lugar e ao conjunto maior, o que tornaria a sua forma dependente desse conjunto. Entretanto, o artista, assim como o artesão, no exercício de sua artesania, deveriam ser trabalhadores comuns, e não aqueles resultantes de uma educação culta. As diversas naturezas da arte estariam ligadas, ao mesmo tempo, ao dom natural e ao exercício oficinal. Ruskin (1903, v. I, p. 283-309).

12. Deve-se ressaltar que a materialidade produzida pelo artista ou pelo artesão deveria revelar um equilíbrio entre prazer $\mathrm{e}$ propósito moral. Ou seja: o trabalhador ou o artista não poderiam trabalhar sem prazer; no entanto, não poderiam trabalhar, também, somente por causa do prazer. Da mesma forma, a materialidade por eles produzida deveria ser admirada tanto pelo prazer que proporcionava quanto pelo propósito moral que revelava. Ruskin (1905, p. 197).

13. Ruskin (1904, v. II, p. 188-190).

14. Ruskin (1904, v. II, p. 204-205, tradução nossa). No original: "The degree in which the workman is degraded may be thus known at a glance, by observing whether the several parts of the building are similar or not; and if, as in Greek work, all the capitals are alike, and all the mouldings unvaried, then the degradation is complete; if, as in Egyptian or Ninevite work, though the ligado à sua fatura. Qualquer trabalho humano que fosse realizado para nos causar emoção e prazer, principalmente aquele desempenhado na arquitetura, deveria ser, segundo Ruskin, a revelação de um exercício artístico-moral, mas deveria revelar também a felicidade do trabalhador que ajudou na edificação de tal obra, entregando, além do seu corpo e do seu trabalho, o seu espírito e a sua inventividade. A obra produzida ganharia valor estético, portanto, se fosse feita por um homem bom - religioso, ético e moral - e por um homem feliz completamente envolvido em sua execução e que deixaria inscrito, impregnado naquela matéria, o prazer que sentiv em executá-la. Somente uma matéria feita por um homem bom e por um homem feliz educaria plenamente, porque o autor entendia que as virtudes presentes no artista ou no artífice estariam presentes também na coisa por eles produzida. E a obra, assim criada, teria o poder de ascender, naquele que fosse usufruíta, as mesmas virtudes. Existiria, portanto, uma ligação entre aquele que faz, a coisa produzida e aquele que frui a coisa, que o autor chamava de "irmandade eterna". E essa ligação testemunha o inquestionável vínculo entre ética e estética que alimenta todo o pensamento ruskiniano.

O trabalho na arquitetura deveria, então, considerar o trabalhador em sua completude, tanto executiva quanto inventiva. E a arquitetura gótica representava, para o autor, um exemplo dessa partilha entre $\circ$ trabalho das mãos e o trabalho do intelecto, em que o artífice podia participar diretamente na elaboração da obra, esforçando-se para realizar o seu melhor e confessando, ao mesmo tempo, as suas incapacidades. ${ }^{13}$ Segundo Ruskin, "o nível de degradação do trabalhador poderia ser reconhecido observando se as várias porções de um edifício eram similares ou não". Como na arquitetura gótica havia variação "tanto no desenho quanto na execução do edifício", Ruskin considerava que o trabalhador deveria "ter sido completamente liberto" 14 no exercício de sua atividade. Essa variação representava o testemunho concreto da liberdade executiva do trabalhador gótico consagrada, sobretudo, por meio da imaginação e da "saudável alegria da fantasia". E um dos principais elementos de poder na natureza da arquitetura gótica residiria, para o autor, na aceitação dessa "energia inculta e rude do trabalhador". ${ }^{15}$ Somente ao reconhecer a fantasia grotesca e a rudeza de expressão do homem comum é que a sua imaginação poderia ser alimentada em seu trabalho diário. Se não pudesse produzir uma obra que revelasse os requintes de uma beleza formal, o trabalhador poderia produzir uma obra que revelasse a sua energia vital, porque constituída por uma imaginação saudável. Para o pensamento ruskiniano, "no feitio e natureza de cada homem que empregamos no trabalho manual, por mais simples ou rude que seja", seus poderes de imaginação, emoção e pensamento não poderiam ser fortalecidos, "a menos que nos contentássemos em tomá-los em sua debilidade, em 
valorizá-los e honrá-los em sua imperfeição, para além da melhor e da mais perfeita habilidade manual". ${ }^{16}$

Uma das grandes críticas do pensamento ruskiniano em relação ao Renascimento e à Inglaterra vitoriana repousava, justamente, na não mais aceitação dessa energia inculta e rude do trabalhador. Para Ruskin, a escola renascentista, com a completude dos seus grandes mestres, nos colocou uma habilidade executiva de primeira ordem e, a partir de então, a perfeição passou a ser exigida por nossos olhos, uma vez que já não podíamos mais nos satisfazer com uma "execução menos requintada" ou com um "saber menos completo". A exigência da perfeição na pintura e na escultura não teria sido tão nociva, segundo Ruskin, porque o trabalho se desenvolve, normalmente, de maneira solitária. A arquitetura, porém, é uma arte de natureza partilhada e requerer a perfeição executiva de simples trabalhadores tornou-se, para o autor, um dos seus maiores erros. E, ao tentar atribuir ao trabalhador comum as habilidades dos grandes mestres, o poder manifestado em sua fantasia e em sua rudeza de expressão dava lugar, segundo Ruskin, ao "método" e ao "apuro" na busca pelo refinamento, sacrificando seu corpo, sua alma e seu pensamento. ${ }^{17}$ Ao aproximar a arte da ciência, o Renascimento demonstrava um dos principais elementos de fraqueza da sua natureza - "o orgulho do conhecimento". Tal orgulho "não somente impediu toda a rudeza na expressão, mas gradualmente extinguiu toda a energia que somente poderia ser rudemente expressada." 18 Para o autor, a partir do momento em que os conhecimentos da ciência ${ }^{19}$ passaram a ser vistos como a essência da arte, e não mais como seu suporte, quando a técnica começou a sobrepor a emoção e a natureza da alma humana, a prática artística dava os primeiros passos de sua corrupção. De acordo com Ruskin, o dom natural que não recebeu fina educação, conhecimento e a polidez acadêmica acabava se perdendo numa sociedade que julgava ser capaz de produzir artistas. "Tenho certeza de que há, na Europa, muitos lavradores e camponeses dotados de uma imaginação de primeira ordem que nunca servirá para nada, porque só admitimos considerar o que passou pela ordem legal e científica" ${ }^{20}$

Contudo, a técnica, a ciência, e a capacidade executiva manifestadas nas melhores obras do Renascimento não eram, de forma alguma, desprezadas por Ruskin, desde que fossem o resultado natural da expressão da natureza humana daqueles que entregaram trabalho e pensamento na execução de tais obras. Estes homens, que conseguiam expressar a mais nobre arte e que tinham o poder de reunir verdade e invenção em seu trabalho expressivo, seriam aqueles que tornaram, segundo o autor, o período renascentista memorável: "A força desses grandes manner of executing certain figures is always the same, the order of design is perpetually varied, the degradation is less total; if, as in Gothic work, there is perpetual change both in design and execution, the workman must have been altogether set free."

15. Ruskin (1904, v. III, p. 200).

16. Ruskin (1904, v. II, p. 191, tradução nossa). No original: "Now, in the make and nature of every man, however rude or simple, whom we employ in manual labour, there are some powers for better things; some tardy imagination, torpid capacity of emotion, tottering steps of thought, there are, even at the worst; and in most cases it is all our own fault that they are tardy or torpid. But they cannot be strengthened, unless we are content to take them in theirfeebleness, and unless we prize and bonour them in their imperfection above the best and most perfect manual skill." Ainda segundo o autor, para cada trabalhador que possui o mais fino instinto para a expressão da perfeição da beleza em linhas e cores, 20 possuem um humor árido e uma fantasia mais rude. Isso não quer dizer que as faculdades do segundo tipo fossem dadas em maior número aos homens do que as do primeiro, e sim, que estas seriam mais exercidas nas relações diárias e desenvolvidas pelos interesses que tomamos nos assuntos da vida, enquanto aquelas não. Ruskin (1904, v. III, p. 157).

17. Ruskin (1992, p. 111113).

18. Ruskin (1904, v. III, p. 200, tradução nossa). No original: "In examining the nature of Renaissance, we concluded that its chief element of weakness was 
that pride of knowledge which not only prevented all rudeness in expression, but gradually quenched all energy which could only be rudely expressed."

19. A ciência, no pensamento ruskiniano, deveria ser, sobretudo, um dos "alimentos do espírito", mas não o único, de forma que ela, utilizada sem excessos, não paralisaria a energia vital do homem e a sua força imaginativa. Ruskin (1992, p. 132-133).

20. Ruskin (1992, p. 74), edição em português. No original: "[...] I believe there are many peasants on every estate, and labourers in every town, of Europe, who have imaginative powers of a bigh order, which nevertheless cannot be used for our good, because we do not choose to look at anything but what is expressed in a legal and scientific way." Ruskin (1904, v. II, p. 129).

21. Ruskin (1992, p. 113), edição em português. No original: "Their strength was great enough to enable them to join science with invention, method with emotion, finish with fire." Ruskin (1904, v.III, p. 17). A crítica de Ruskin em relação ao Renascimento não parece se referir aos preceitos que regulam tal escola. $\mathrm{O}$ modelo e a imitação de padrões clássicos são criticados não pela disposição que regem, mas quando as certezas teóricas que postulam se sobrepõem à alma humana, seja do artista ou do artífice.

22. Ruskin (1904, v. II, p. 192, tradução nossa). No original: "Let him but begin to imagine, to think, to try to do anything worth doing; and the engine-turned precision is lost at once. Out come all his roughness, all his dulness, all bis homens era bastante poderosa para que eles pudessem unir a ciência à invenção, o método à emoção, o apuro ao fogo da inspiração."21

Se a perfeição ensinada do Renascimento ignorava a presença viva do trabalhador, a perfeição fabril da sociedade industrial, acentuada no século XIX, igualmente desconsiderava a dignidade da natureza do operário empregado no trabalho manual, exigindo a precisão executiva de uma máquina. Contudo, a natureza humana, de acordo com o pensamento ruskiniano, não fora destinada a trabalhar com a precisão de uma máquina, nem os homens a "serem precisos e perfeitos em todas as suas ações". E exigir a perfeição executiva ali onde não há qualquer liberdade de pensamento era, para o autor, um trabalho servil, não um trabalho liberto: "Deixe [o trabalhador] apenas começar a imaginar, a pensar e a tentar fazer qualquer coisa digna de ser feita e a precisão maquinal se perde de uma só vez. Disso emerge toda a sua rusticidade, toda a sua lentidão", embora disso também resulte "toda a sua majestade". ${ }^{22}$

Vale a pena ressaltar que a imperfeição revelada tanto na rudeza de expressão quanto na fantasia grotesca em nada se aproxima de uma manifestação descuidada ou negligente. Isso porque o fantástico paradoxo da imperfeição estaria fundamentado em duas razões assentadas naquilo que Ruskin chamava de "leis eternas". A primeira delas nos diz que a mente humana estaria sempre muito mais adiante do que a nossa capacidade executiva e, nesse sentido, qualquer trabalho do homem, seja de um artista ou de um trabalhador comum, seria, pela condição da própria natureza humana, imperfeito, "apesar de belo". A segunda lei nos diz que a imperfeição seria a expressão da vida que pulsa num "corpo mortal", uma vez que nada daquilo que é vivo na natureza pode ser completamente perfeito - "parte está decaindo e parte está nascendo"; e residiria, sobretudo, nas irregularidades que se mostram na coisa viva a sua maior beleza. Contudo, isso não significa que o autor negasse a beleza em sua forma perfeita ou que celebrasse a precariedade da expressão formal. Segundo Ruskin, a lei que deveria reger a vida humana seria a lei do "Esforço" e, nesse sentido, a perfeição estaria, de certo modo, sempre impulsionando as ações humanas. Por outro lado, a lei que deveria julgar a vida humana seria a lei da "Misericórdia" e, dessa forma, o juízo que se deveria fazer das ações e das coisas produzidas pelo homem deveria ser alimentado pela compaixão e pelo reconhecimento da imperfeição como uma condição humana, "divinamente estabelecida". ${ }^{23}$ Cumpre sublinhar ainda que perfeição e imperfeição não estão contrapostas em seu pensamento. Ambas deveriam ser a manifestação da vida na matéria produzida pelo homem em seu trabalho expressivo. Se a perfeição fosse atingida naturalmente, mantendo-se a plenitude de vida na comunhão entre trabalho e pensamento, a beleza ali residiria, 
mas se para atingi-la toda a imperfeição, que constitui a natureza do homem comum, tivesse de ser controlada, restando apenas um homem inanimado que produz algo igualmente sem vida, o verdadeiro caráter da beleza teria se perdido por inteiro.

Ao escrever principalmente sobre a arquitetura e mais adiante sobre a economia política da arte, Ruskin voltava o seu olhar para o homem comum e para o seu trabalho expressivo porque considerava que a arquitetura, além de ser uma arte mais próxima da vida diária, dependia, para sua construção, da colaboração de trabalhadores comuns. Dessa maneira, a sua edificação acabava por influenciar a vida cotidiana de uma grande quantidade de homens, seja na fruição da obra arquitetônica - por ser uma arte pública -, seja em sua fatura - por ser uma arte partilhada.

Considerando a arquitetura como uma arte partilhada e constituinte da vida cotidiana, nos debruçaremos, agora, sobre o trabalho do artesão imigrante, que edificou a sua moradia e ajudou a dar corpo à arquitetura rural catarinense, buscando recuperar a presença viva do seu trabalho na materialidade por ele construída. Tal materialidade tanto testemunha o ofício do artífice imigrante quanto alimenta 0 trabalho de artesãos que ainda hoje resguardam um saber-fazer de técnicas construtivas tradicionais transmitidas entre gerações. Aproximar tanto as expressões da arquitetura rural realizadas pelo artífice imigrante quanto os saberes construtivos guardados por seus descendentes das concepções do pensamento ruskiniano apresenta-se como uma proposta para iluminar outras formas de analisar tais manifestações - uma proposta metodológica que se mostra como alternativa e que talvez possa contribuir para compreender de maneira singular a arquitetura e os saberes por ela revelados.

\section{A BELEZA PITORESCA NA ARQUITETURA RURAL}

Grande parte da paisagem rural catarinense formou-se a partir da contribuição de imigrantes que começaram a se instalar, mais intensamente, em meados do século XIX. Formando colônias principalmente de alemães e de italianos, tais imigrantes mantiveram seus costumes e seus modos de vida ao mesmo tempo em que se adaptaram às novas realidades encontradas e incorporaram novos hábitos. ${ }^{24}$ Dentre as várias expressões que caracterizam uma cultura, a arquitetura e os saberes por ela revelados são de fundamental importância para a formação de um território. Os imigrantes que se instalaram nas terras catarinenses, ao se incapability; shame upon shame, failure upon failure, pause after pause: but out comes the whole majesty of bim also."

23. Ruskin (1904, v. II, p. 202-204).

24. Cf. Weimer (2012); Seyferth (1990). 
25. Em 1876, o presidente da Província de Santa Catarina, Alfredo d'Escragnolle Taunay, visitou terras no sul da província e, admirado com a região, sugeriu ao governo imperial a formação de núcleos coloniais nos vales do Tubarão e do Araranguá. Desta solicitação formou-se a comissão chefiada pelo engenheiro maranhense Joaquim Vieira Ferreira. A Colônia Azambuja foi fundada em 28 de abril de 1877, com a chegada de 291 imigrantes, quase todos de origem italiana. No ano seguinte, em 1878, o engenheiro fundou a Colônia Urussanga - uma sede secundária, mas a extensão mais importante da Colônia Azambuja. Além dos trabalhos de medição dos lotes e de preparação para o recebimento dos imigrantes, Joaquim Vieira Ferreira ficou encarregado de dirigir a colônia. Em 1880, Joaquim propõe a emancipação da Colônia Azambuja, na extensão que compreendia os vales de Pedras Grandes, Armazém e parte de Urussanga, mantendo sob a tutela do Estado a região do Baixo Urussanga e Criciúma. O engenheiro permaneceu como diretor da colônia até meados de 1881 e, no final desse mesmo ano, Azambuja foi emancipada. Cf. Mattos (1917); Ferreira (1939).

26. A figura do padre João Leonir Dall'Alba se mistura com a formação do conhecimento da história da cidade de Orleans, em Santa Catarina. Com uma narrativa de natureza empírica, buscando tanto constituir a história da cidade quanto relatar a vivência e os saberes dos imigrantes que ajudaram na sua constituição, Dall'Alba publicou vários livros que manifestam sua relação afetiva com a cidade. Foi, também, um dos apropriar de seus terrenos, ao se acomodar ao relevo dos lugares, ao edificar suas moradias, e ao construir suas pequenas indústrias caseiras, condicionaram a constituição formal e paisagística dessas colônias. Além disso, a natureza rural se apresentava, também, como corpo de trabalho ao artífice imigrante, que dela retirou sua matéria e nela inscreveu suas habilidades técnicas baseadas em seus modos de saber-fazer.

Considerando o sul do estado de Santa Catarina, uma região colonizada por imigrantes italianos, especialmente a cidade de Urussanga, ${ }^{25}$ é possível perceber a contribuição técnica dos artífices que ali se estabeleceram. De acordo com o relato do padre Dall'Alba, ${ }^{26}$ um importante pesquisador dessa região, teria sido no desenvolvimento das máquinas que os imigrantes italianos melhor demonstraram sua capacidade técnica. ${ }^{27}$ A região de Urussanga, segundo ele, depois de um rápido crescimento inicial, ${ }^{28}$ teria mergulhado num longo período de estagnação em função, principalmente, da falta de estradas de acesso, o que dificultava tanto a entrada quanto a saída de produtos. Essa situação acabou obrigando os colonos daquela região a produzir quase tudo e a utilizar o sistema de trocas por muito tempo. Para Dall'Alba, ${ }^{29}$ os imigrantes italianos teriam encontrado na madeira ${ }^{30}$ uma de suas grandes fontes materiais, fabricando desde utensílios domésticos até máquinas. Os marceneiros desenvolveram suas indústrias de móveis, enquanto os carpinteiros, suas habilidades como construtores. E, utilizando várias quedas-d'água da região, colocaram em movimento as mais variadas pequenas indústrias. ${ }^{31}$

Situado numa localidade conhecida como Rio América Baixo, na zona rural da cidade de Urussanga, o conjunto de bens tombados da família Bez Fontana ${ }^{32}$ pode ser considerado um exemplo da engenhosidade técnica demonstrada pelos italianos. Tal engenhosidade mostra-se, principalmente, no sistema de rodas-d'água desenvolvido pelos primeiros imigrantes da família e que permanece resguardado no sítio. A primeira roda-d'água existente colocava em movimento o antigo moinho da atafona, o descascador de arroz e a carpintaria. A segunda roda alimentava a serraria e a marcenaria, sendo que esta última ainda se encontra em funcionamento no conjunto tombado e, até bem pouco tempo atrás, tinha uma de suas máquinas alimentada pela roda-d'água. Todo o sistema começa pelo desvio do curso de água, sinuosamente esculpido ao longo da encosta do morro (figura 1). Feita artesanalmente em madeira e sustentada por colunas igualmente construídas com o mesmo material, a calha mantém-se elevada no mesmo nível da parte do morro em que surge para depois lançar-se numa grande queda, acompanhando o desnível do sítio (figuras 2 e 3). E a água, que antes percorria lentamente as valas talhadas na encosta, agora toma corpo e cai vigorosamente na parte superior da 


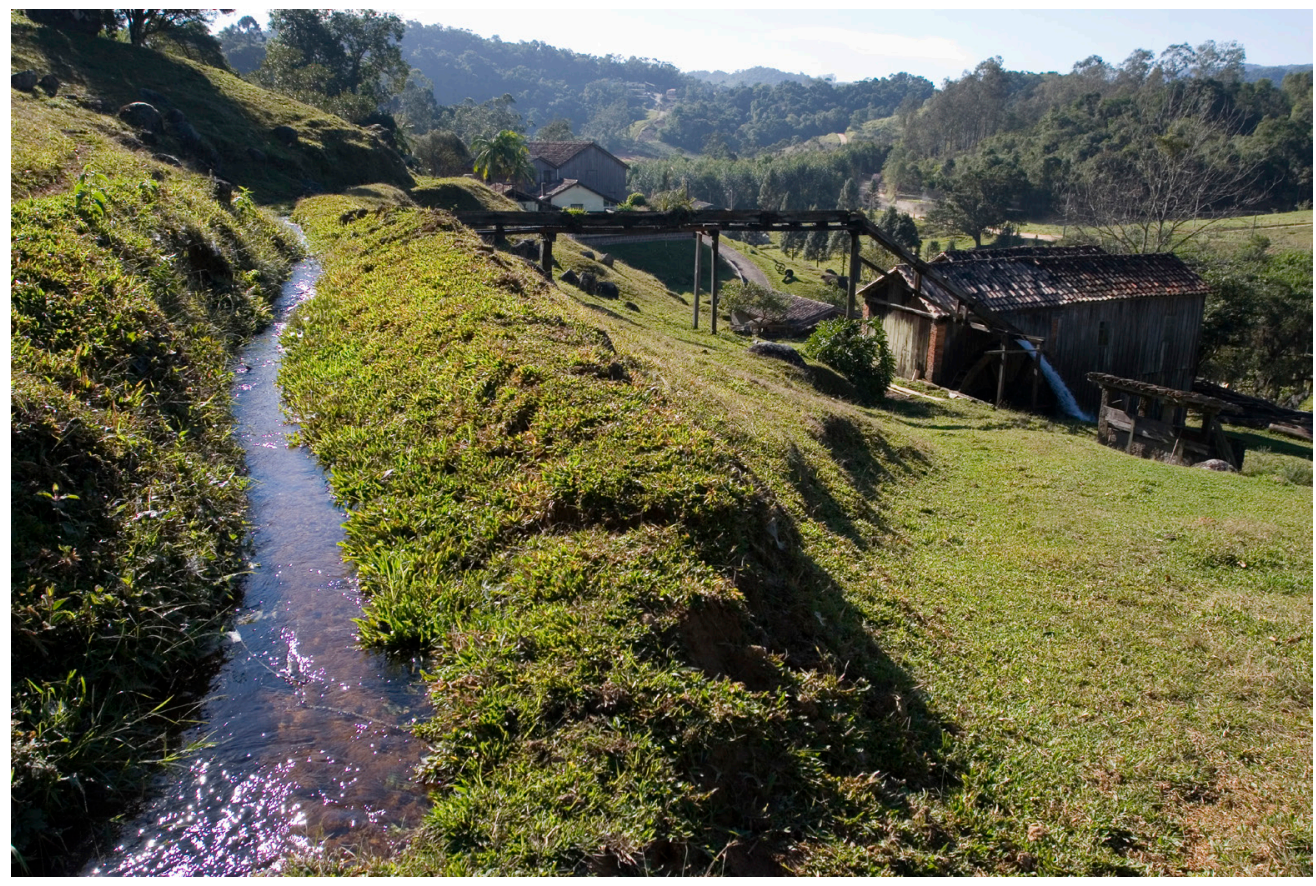

Figura 1 - Propriedade Bez Fontana. Detalhe da vala esculpida na encosta do morro, 2005. Foto: IPHAN/SC; Tempo Editorial.

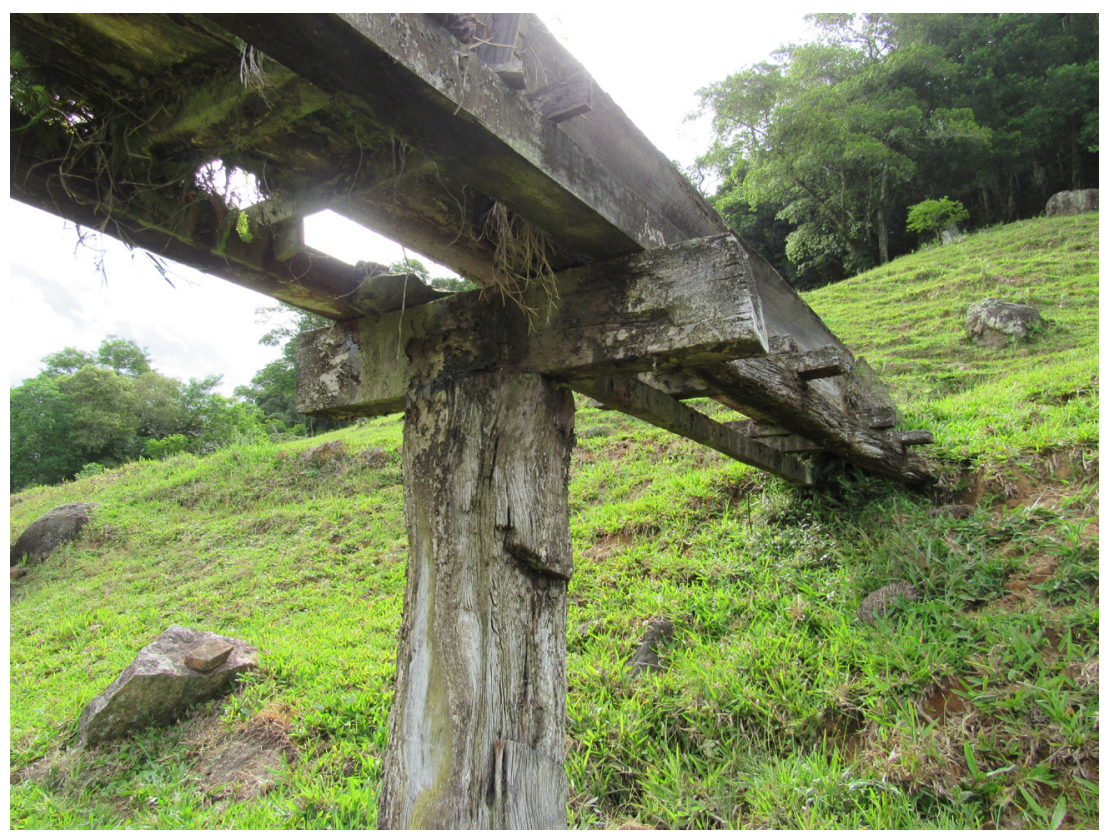

Figura 2 - Detalhe da calha de madeira, 2017. Fotografia do autor. idealizadores do Museu ao Ar Livre Princesa Isabel, localizado na mesma cidade. A partir de um patrimônio material que abrange vários tipos de edificações e técnicas construtivas em madeira, o Museu ao Ar Livre tem por objetivo a preservação da cultura material praticada principalmente por imigrantes, além de servir como importante acervo documental e histórico. Entretanto, mesmo considerando a contribuição de todo o seu trabalho na construção da história da cidade, devemos considerar, também, as idiossincrasias que caracterizam um relato de natureza empírica e afetiva.

27. Dall'Alba. In: De Boni (1987, p. 164-165).

28. Durante este período de crescimento inicial, mesmo sendo apenas um núcleo da Colônia Azambuja, Urussanga logo viria a se tornar o centro da colonização italiana, segundo Dall'Alba, com muitos engenhos, moinhos, ferrarias, transformando-se em distrito de Tubarão, em 1890, e emancipando-se em 1900. Dall'Alba. In: De Boni (1987, p. 155-156).

29. Ainda de acordo com o relato de Dall'Alba, essa situação de autoprovimento não teria acontecido somente no início da colonização. "Na região sul de Santa Catarina, caminhões só entraram depois de 1940. Só depois de 1970 houve estradas asfaltadas, só depois de 1975 houve eletrificação rural", enquanto em outras regiões coloniais a "nova civilização" teria chegado bem antes. Para Dall'Alba, com a grande enchente de 1974, a ordem até então estabelecida sofreu uma grande revolução e teve de se modificar de maneira 
drástica. "De uma idade média passou-se direto ao mundo contemporâneo". Dall'Alba. In: De Boni (1987 p. $165-166)$.

30. Considerando os imigrantes italianos no Rio Grande do Sul, Weimer (2012, p. 170-177) também afirma que, embora estes tivessem maior ligação com a pedra como material construtivo, a madeira logo teria se transformado numa matéria-prima para exploração artesanal e industrial e, nesse sentido, as construções em tábuas representariam a capacidade de adaptação desses imigrantes.

31. As observações feitas sobre a engenhosidade técnica dos imigrantes italianos da região de Urussanga também conduziram os relatos do padre Luigi Marzano. Segundo Marzano (1985, p. 60), antes da chegada dos italianos, "contavam-se nos dedos de uma mão" os moinhos em Santa Catarina e as mós, que vinham do Rio de Janeiro, eram tocadas a tração animal.

32. O processo de tombamento federal das edificações da propriedade Bez Fontana se iniciou em 2007. A inscrição nos livros do Tombo Histórico, Belas Artes, Etnográfico, Paisagístico e Arqueológico foi feita em 2015. A propriedade Bez Fontana também integra os Roteiros Nacionais de Imigração de Santa Catarina. Para mais informações sobre o processo de tombamento, cf. Iphan ([s. d.]a; [s. d.]b).

33. De acordo com o Glossário dos Carpinteiros de Moinho, de Júlio Katinsky, o termo calha designa o "conduto de água a céu aberto" que serve para conduzir a água até à rodad'água, sendo que o último trecho, chamado de cale, é

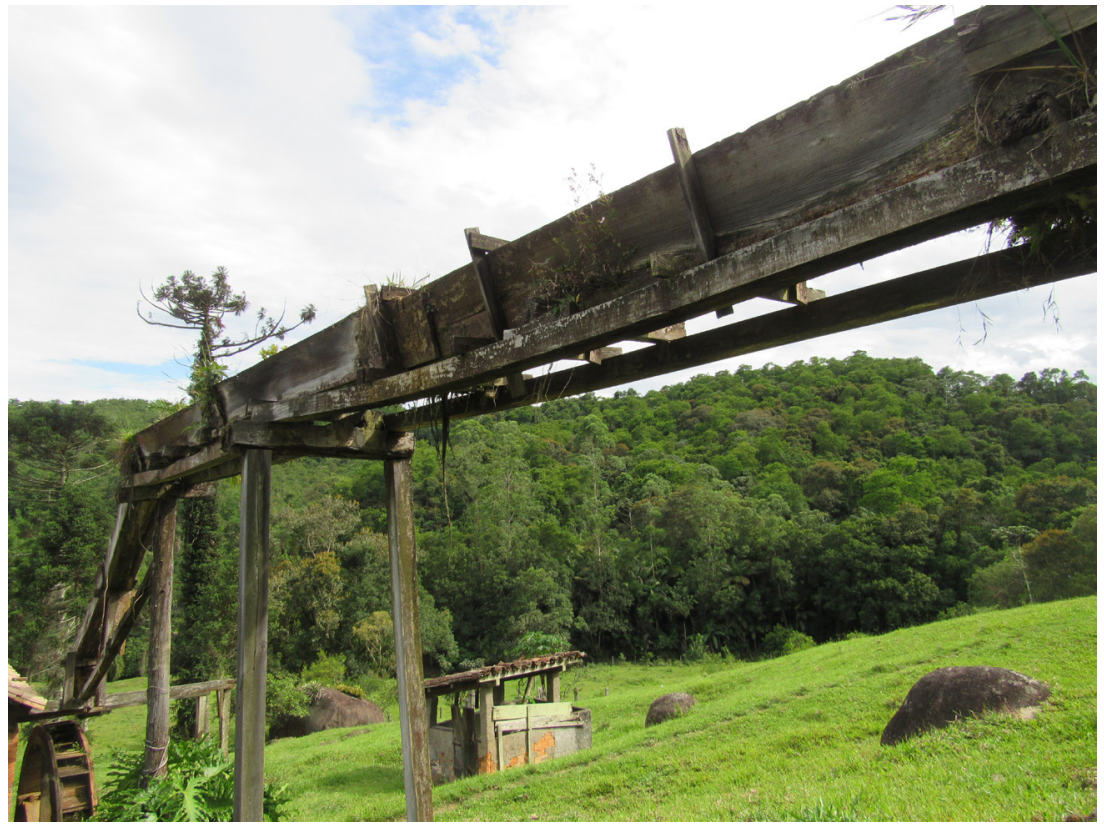

Figura 3 - Calha de madeira, 2017. Fotografia do autor.

imensa roda. Essa roda-d'água, construída ao lado do primeiro edifício, hoje está desativada. Mas o espetáculo da engenhosa cascata continua a constituir a sonoridade rumorosa que dá vida a esse sítio. Mesmo em repouso, a roda-d'água ainda impressiona pela grandiosidade de suas proporções, por sua engenhosidade construtiva e pela simplicidade de suas formas. Seu desenho toma parte tanto do edifício construído quanto da paisagem circundante.

Na rudeza das calhas ${ }^{33}$ é possível perceber a presença do trabalho do artífice. Nela ele conjuga as habilidades técnicas à conveniência de um declive que conduz a água ao seu destino motriz. A madeira utilizada evidencia vários episódios construtivos, a julgar pela convivência entre os cortes regulares em algumas partes de sua estrutura e a aparência natural em outras, uma vez que, segundo os relatos da família, os reparos necessários para o funcionamento tanto das calhas quanto das rodas-d'água sempre foram feitos pelos próprios artífices no exercício cotidiano de seu ofício. $\bigcirc$ corpo da calha em madeira apoia-se numa estrutura tramada e têm suas laterais travadas por tarugos na parte superior. As variações e irregularidades entre os espaçamentos da trama e dos tarugos revelam a presença da mão artesanal e o conhecimento empírico do artífice. Ademais, a rusticidade da cor natural da madeira e as singularidades próprias de sua natureza material colaboram para integrar a presença do trabalho humano à paisagem natural (figuras 2, 3 e 4). 
Depois de cair sobre a roda da atafona (figura 5), a água segue seu curso por meio de outra vala talhada diretamente no solo plano abaixo da edificação (figuras 8,15 e 16) e, assim, é conduzida até encontrar outra calha de madeira que surge um pouco antes do morro sofrer outro declive. Essa calha, da mesma forma que a anterior, também é sustentada por colunas de madeira que a mantêm acima do nível do declive, para depois lançar-se, novamente, numa grande queda. Após cair sobre a roda-d'água da marcenaria (figura 18), a água retoma o fluxo do rio, desaguando num riacho que circunda todo o sítio e o separa da rua.

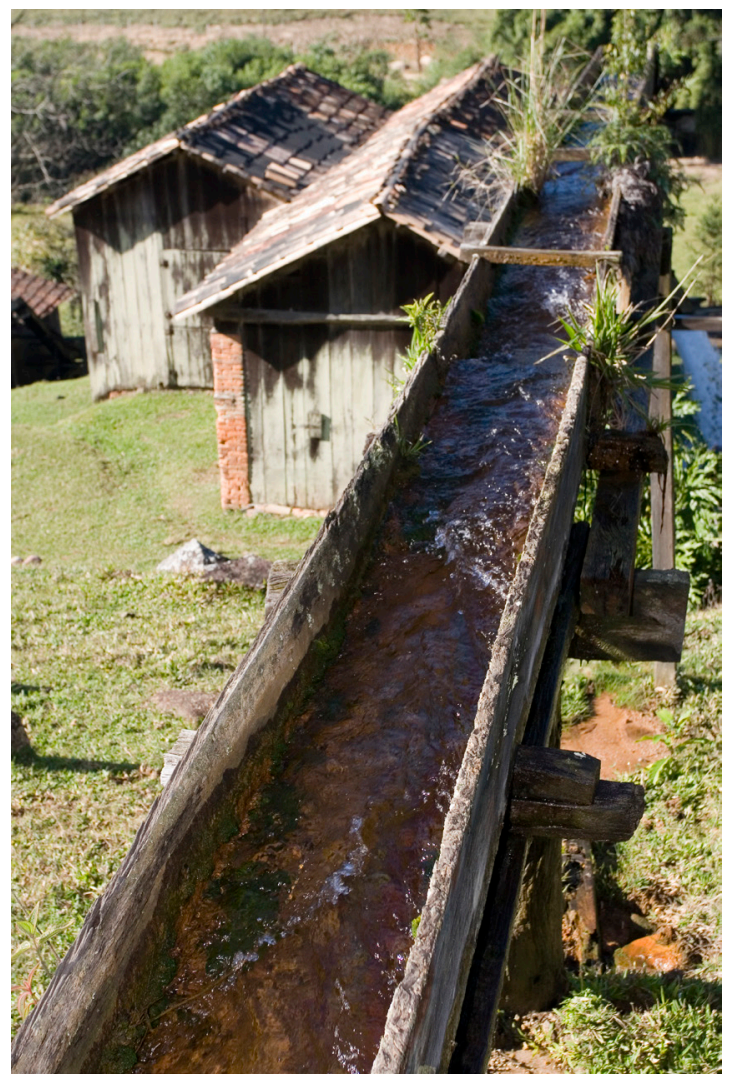

Figura 4 - Detalhe da calha da atafona, 2005. Foto: IPHAN/SC; Tempo Editorial. feito geralmente em madeira com uma "secção retangular" e um dispositivo que "permite movimentar ou parar a roda d'água”. Katinsky. In: Gama (1985, p. 230).

Com aproximadamente cinco metros de diâmetro, as duas rodas foram feitas totalmente em madeira e parecem seguir o mesmo sistema construtivo. São compostas por duas "coroas circulares", feitas de "cambotas" de madeira, como se a circunferência tivesse sido dividida em partes até formar o círculo. Essas duas coroas são unidas por pequenas tábuas inclinadas, encaixadas na parte interna por meio de fendas igualmente inclinadas, que formam recipientes que recebem a água. As coroas se unem ao eixo da roda por meio de caibros que, segundo Katinsky, "trabalham predominantemente a tração" e teriam o trabalho "inverso ao 
34. Katinsky. In: Gama (1985, p. 233). As terminações técnicas aqui utilizadas se baseiam no já mencionado Glossário dos Carpinteiros de Moinho, de Júlio Katinsky. Embora tal glossário tenha sido feito baseado no vocabulário de carpinteiros de moinhos hidráulicos da região sudeste, acredita-se que haja alguma proximidade em suas práticas, a julgar pela descrição dos termos.

35. A transmissão do movimento da roda-d'água para o interior da marcenaria é feita por um eixo transmissor que acionava uma segunda roda de madeira e, por meio de uma correia, conduzia a energia horizontalmente até uma roda de tamanho reduzido, conhecida como polia, colocada um pouco mais à frente. Esta polia, igualmente feita em madeira, fazia funcionar um novo eixo, que reproduzia o mesmo sistema antes mencionado, acionando uma segunda polia, ligada a uma roda, num tamanho maior. Essa segunda polia transportava o movimento por meio de uma correia que, verticalmente, conduzia a energia para uma terceira polia, igualmente de tamanho reduzido, instalada no primeiro piso da edificação. Essa pequena polia colocava em movimento um novo eixo que, localizado na parte central, fazia funcionar duas outras polias um pouco maiores, que tanto poderiam alimentar máquinas localizadas neste piso quanto levava a energia, novamente por meio de uma correia vertical, para o piso superior da edificação, onde encontravam-se as máquinas da marcenaria.

36. Katinsky. In: Gama (1985, p. 233).

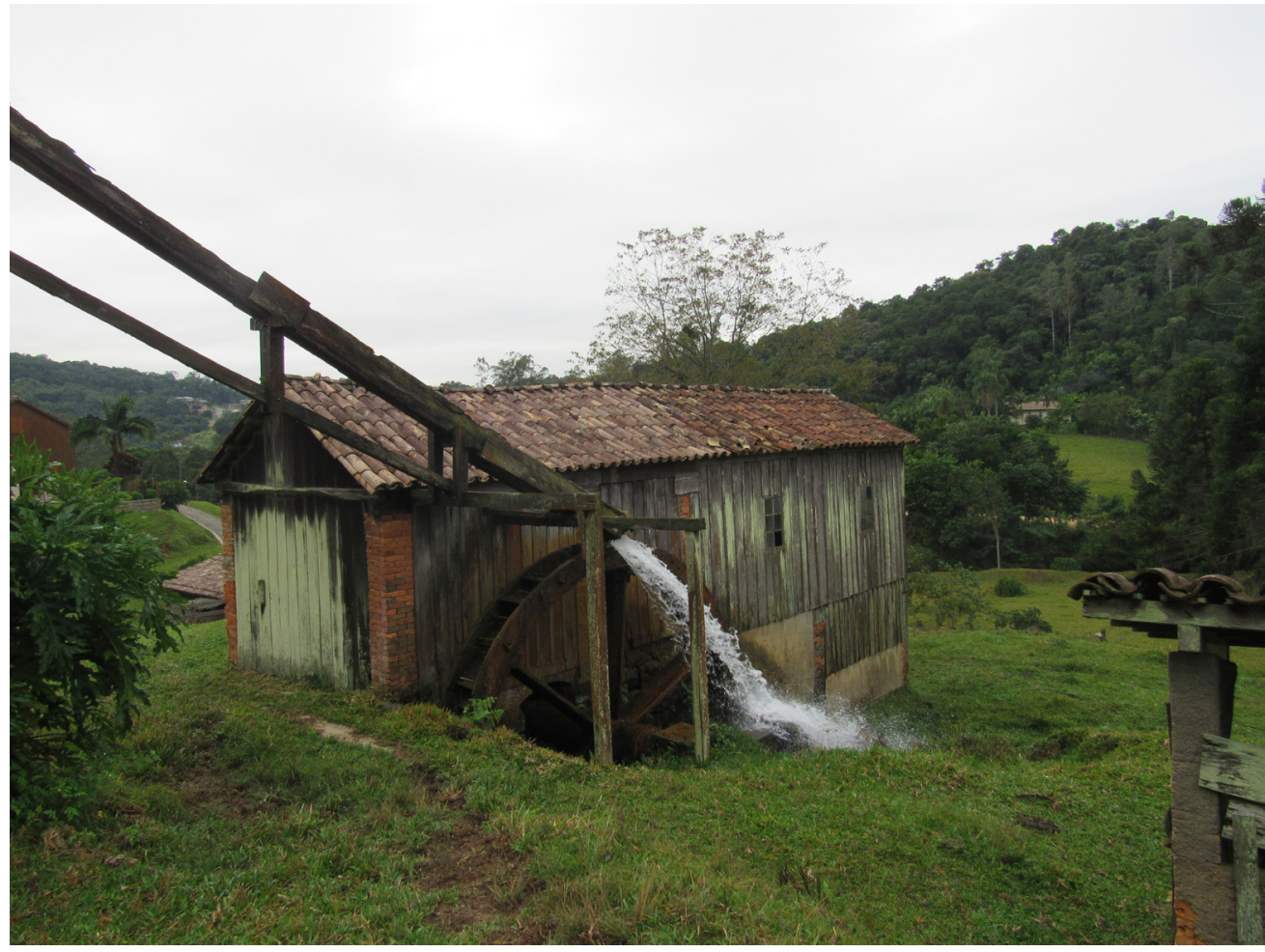

Figura 5 - Atafona e roda-d'água, 2017 . Fotografia do autor.

dos raios da roda de uma carroça". ${ }^{34} \bigcirc$ eixo que transmite o movimento é feito por um largo tronco de madeira que repousa a cabeceira, na parte externa, sobre uma base com uma abertura cilíndrica (figuras 6 e 7). A fabricação da energia mecânica produzida pelas duas rodas-d'água ${ }^{35}$ da propriedade Bez Fontana se dava a partir do seu tamanho e do seu peso - à medida que a água caía sobre a roda e ia enchendo os seus compartimentos, a roda era, então, acionada. Ainda segundo Katinsky, a maneira como a roda é alimentada pela água classificaria o seu engenho: copeiro - quando a água corre na parte superior da roda; copeiro rasteiro - quando a água impulsiona a roda pela parte de baixo; e meio-copeiro - quando a água corre na altura do meio da roda. ${ }^{36}$

A engenhosidade técnica que se mostra no sistema das rodas-d'água da atafona e da marcenaria refere-se aqui aos saberes e às habilidades do ofício de um artífice aplicados ao engenho da coisa fabricada. Tal conhecimento justifica-se não somente pela rudimentariedade da época, que exigia um grande domínio de construção, mas pela ciência necessária à sua fatura, que reclamava por um artesão inteiramente envolvido, empregando seu corpo e seu pensamento em sua fabricação. 

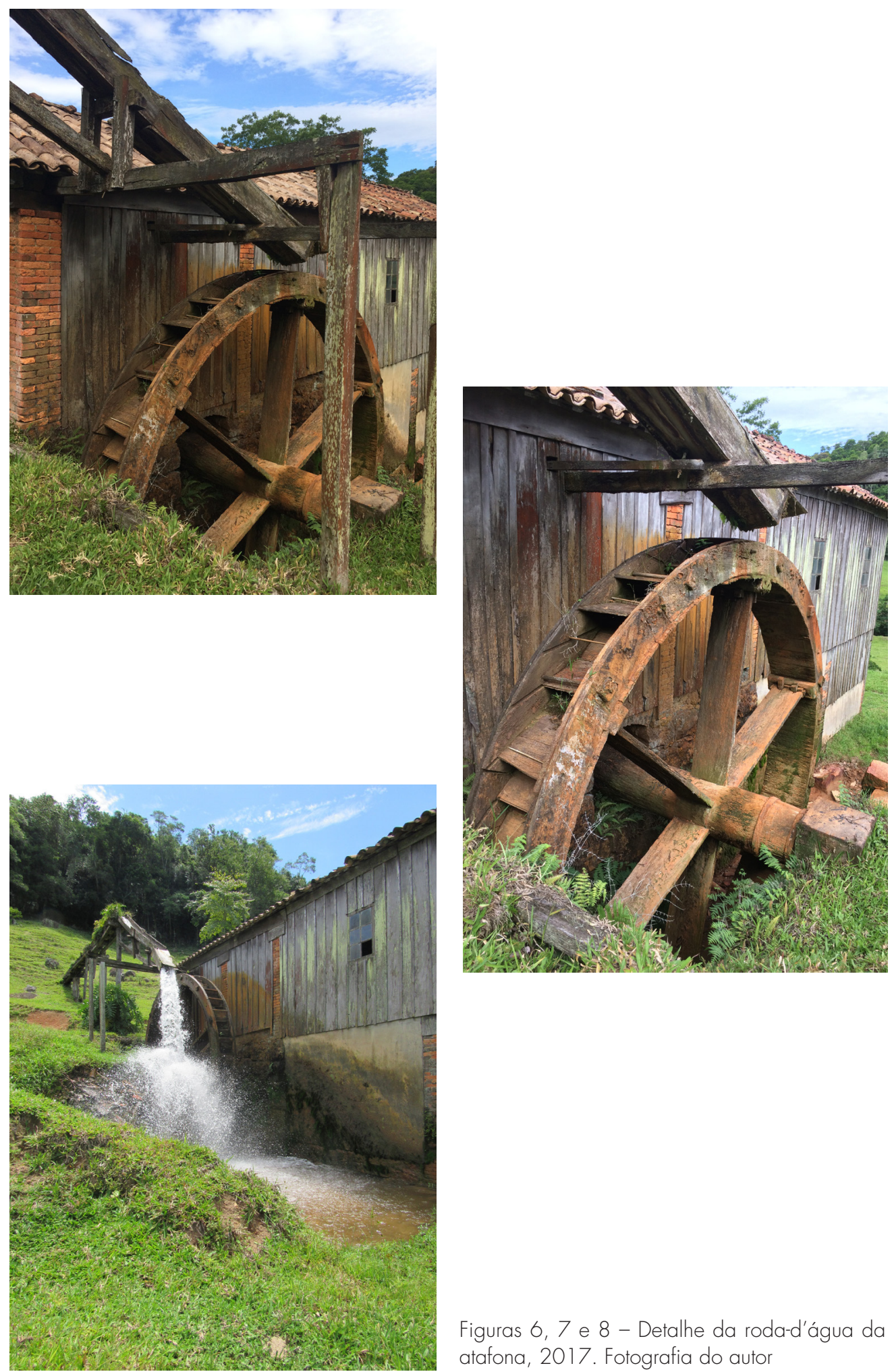

Figuras 6, 7 e 8 - Detalhe da roda-d'água da atafona, 2017. Fotografia do autor 


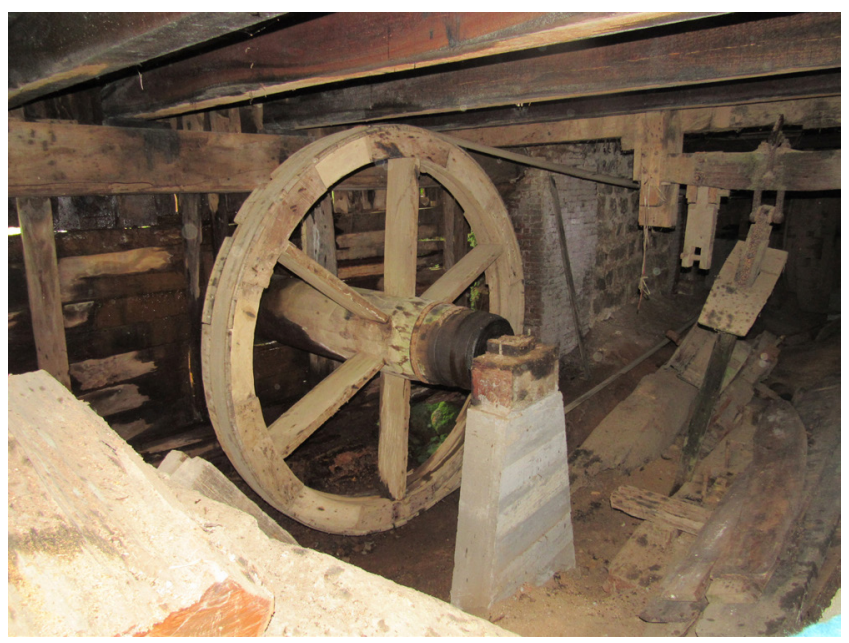

Figuras 9 e 10 - Porão do edifício da marcenaria. Detalhe das engrenagens que transmitem a energia da roda-d'água, 2017. Fotografia do autor.

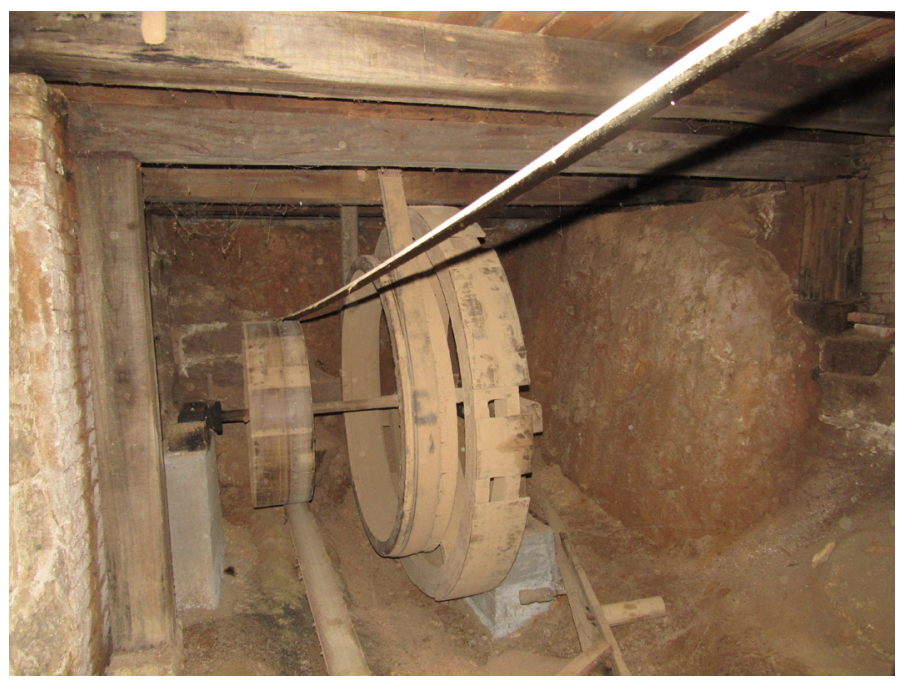

Além das rodas-d'água, o conjunto de bens tombados da família Bez Fontana é formado pelo edifício da atafona, pelo edifício da marcenaria e pela casa da família, todos construídos em madeira. Na chegada à propriedade, o que se vê, então, é um grande volume amadeirado, que se mostra em sua cor natural, desigual por conta da ação do tempo sobre a madeira (figura 11). A julgar pela coloração e pela aparência da superfície, guardam materiais de longa data. Formado por vários níveis de telhados, a matéria bruta do corpo edificado parece espelhar os diversos níveis da encosta do morro, misturando-se à ambiência natural da paisagem da mesma maneira que se acomoda à sua organicidade e aos seus volumes. A simpatia que sentimos ao observar tal cenário evidencia-se, por um lado, nesse agradável encontro entre a obra edificada e a paisagem circundante. Por outro lado, tal simpatia mostra-se, sobretudo, no tempo vivido pelas edificações, que se manifesta 
em sua materialidade e que estabelece uma relação de semelhança entre a arquitetura e o trabalho da natureza. Essa simpatia parece nos aproximar, também, da ideia ou da sensação que nos habituamos a chamar de pitoresco.

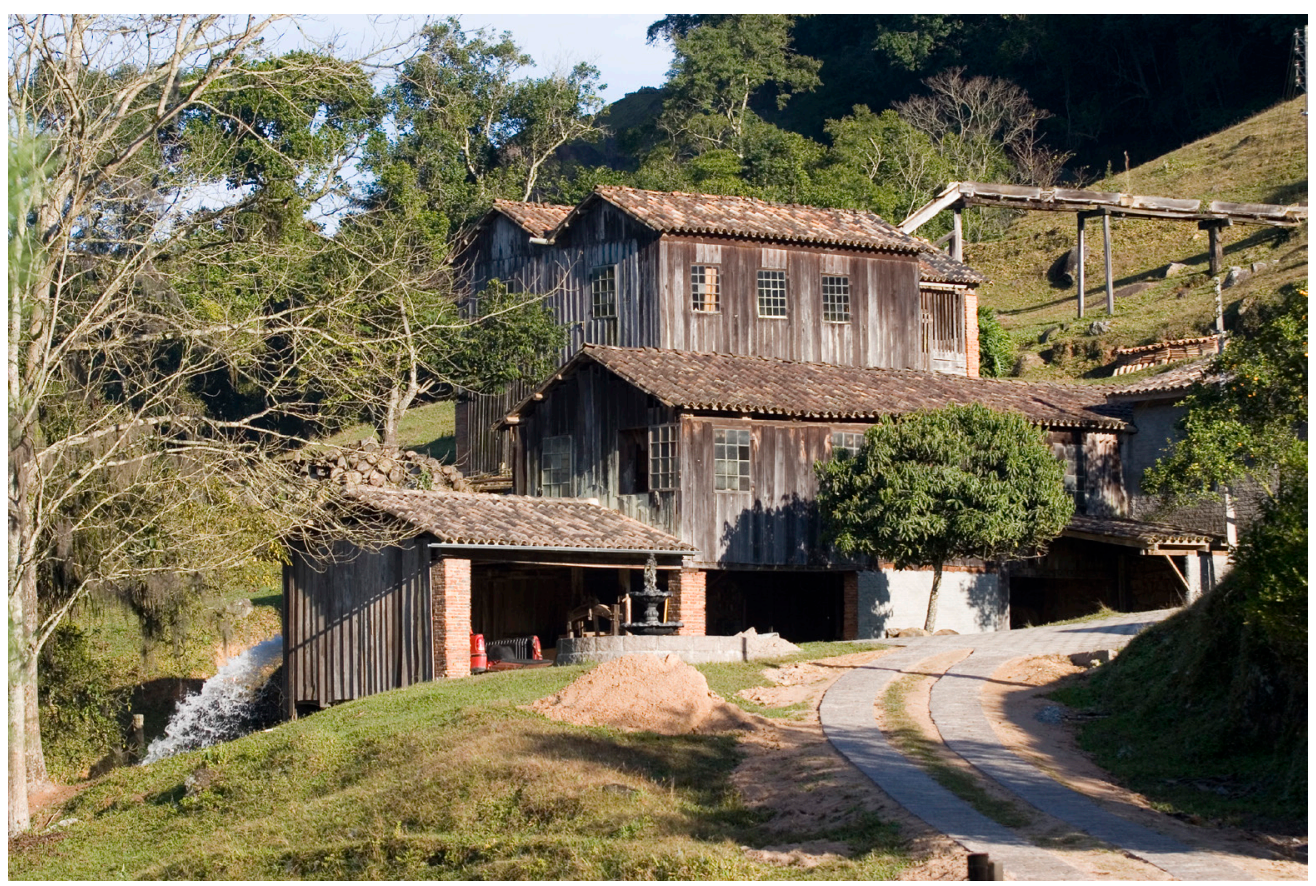

Figura 11 - Vista do conjunto dos edifícios da serraria, da marcenaria e da atafona, 2005. Foto: IPHAN/SC; Tempo Editorial.

Talvez nenhuma outra expressão, segundo Ruskin, tenha sido objeto de julgamentos mal compreendidos, de prolongadas controvérsias e de significações tão frágeis e imprecisas, quanto aquelas feitas com relação às ideias que se formaram em torno do termo "pitoresco". No sentido "etimológico simples" e amplo, Ruskin compreendia o pitoresco como tudo aquilo que está apropriado para tornarse o "tema de uma pintura". Entretanto, em sentido mais estrito, o autor elegia duas ideias que seriam essenciais para a formação de sua natureza e que distinguiria o pitoresco do sublime por meio de preceitos formais presentes no objeto representado. São elas: um certo estado de sublimidade e a posição subordinada ou dependente de tal sublimidade. A característica peculiar que determinaria, então, o significado do pitoresco seria a sublimidade parasitária - uma sublimidade que se forma a partir de "acidentes", ou das "características menos essenciais, dos objetos aos quais pertence". ${ }^{37}$ A porção de sublimidade que caracteriza e que compõe a beleza pitoresca seria sempre parasitária. Ela se manifestaria na superfície da coisa ou nas características acidentais da coisa, mas não constituiria a substância da
37. Ruskin (2013, p. 71), edição em português. No original: "Picturesqueness, in this sense, is Parasitical Sublimity. [...] But that character, of which the extreme pursuit is generally admitted to be degrading to art, is parasitical sublimity; i.e. a sublimity dependent on the accidents, or on the least essential characters, of the objects to which it belongs." Ruskin (1903, p. 236). 
38. Considerando a escultura e a pintura, Ruskin declarava que existiam duas escolas: uma que buscava como tema "as formas essenciais das coisas", e outra que buscava "as luzes e sombras acidentais sobre elas". A primeira era conhecida como "escola pura", a segunda, como "escola pitoresca". Ruskin (2013, p. 72-74).

39. A relação do pitoresco com o sublime no pensamento ruskiniano pode ser observada no texto A noção de pitoresco no debate cultural das primeiras décadas do século $X X$ no Brasil. D'Agostino; Pinheiro (2004, p. 119-127).

40. Pinheiro. In: Ruskin (2013, p. 26-28, apresentação).

41. Ruskin (2013, p. 78-79). coisa em si. Se nos provocassem uma sensação de sublimidade, derivada dos objetos nos quais "a sublimidade verdadeira e essencial existe", os elementos característicos da coisa representada também poderiam produzir o pitoresco. Contudo, se essas características se manifestassem na própria "substância daquilo que nós contemplamos", a arte dela derivada não poderia ser denominada de pitoresca, porque buscaria as formas essenciais das coisas. ${ }^{38}$ Os sentidos do pitoresco e do sublime, no pensamento ruskiniano, não parecem ocupar posições opostas. Entretanto, percebem-se diferenças em relação à natureza de cada um e de como essas diferenças seriam percebidas pelas sensações. ${ }^{39}$

A beleza pitoresca na arquitetura se manifestaria, de acordo com Ruskin, principalmente, ao declarar no corpo mesmo do edifício o tempo vivido pela edificação, quando a arquitetura se tornaria, então, histórica. Segundo Pinheiro, o "elemento-chave" da sublimidade parasitária apresentada por Ruskin em A Lâmpada da Memória seria o tempo e, por assim dizer, a história. A arquitetura, "com a passagem do tempo", em seus longos anos de vida, iria "se impregnando da vida e dos valores humanos". ${ }^{40}$ Entretanto, se as marcas do tempo expressariam os sinais da vida vivida daquela materialidade, os detalhes construtivos de uma edificação também poderiam se beneficiar, segundo Ruskin, do efeito promovido pelo desgaste do tempo, especialmente nas edificações que se mostram mais dependentes dos "pontos de sombra" do que da "pureza dos contornos". Assim, a natureza dos materiais também influenciaria, de alguma maneira, o desenvolvimento da expressão do pitoresco. Segundo o autor, se a forma representada fosse dependente das sombras e das aparências provocadas pela ação do tempo, como o gótico francês, deveriam ser utilizados materiais mais suscetíveis às deteriorações, como a pedra calcária, o tijolo e o arenito, mas se a forma representada estivesse subordinada, de alguma maneira, à pureza da linha, como o gótico italiano, dever-se-ia utilizar materiais mais "duros e não degradáveis", como o mármore e o granito. ${ }^{41}$

O valor histórico que se forma pelo tempo vivido da edificação pode ser entendido, no pensamento ruskiniano, como um encontro fraterno entre homens, principalmente entre homens de gerações diferentes. E, nesse sentido, se a beleza pitoresca na arquitetura toma corpo à medida que o tempo se apossa da matéria, Ruskin se declarava completamente contra qualquer movimento de restauro na arquitetura, pois ele entendia que o restauro retirava do corpo do edifício a sua própria história. Além disso, o restauro também acabava por retirar da matéria mesma da edificação a história e a presença daqueles homens que a fizeram e, principalmente, retirava o direito das gerações posteriores à verdade de sua arquitetura, enquanto ela ainda pudesse existir. Ao homem caberia somente conservar e preservar a arquitetura resguardando o testemunho vital dos seus 

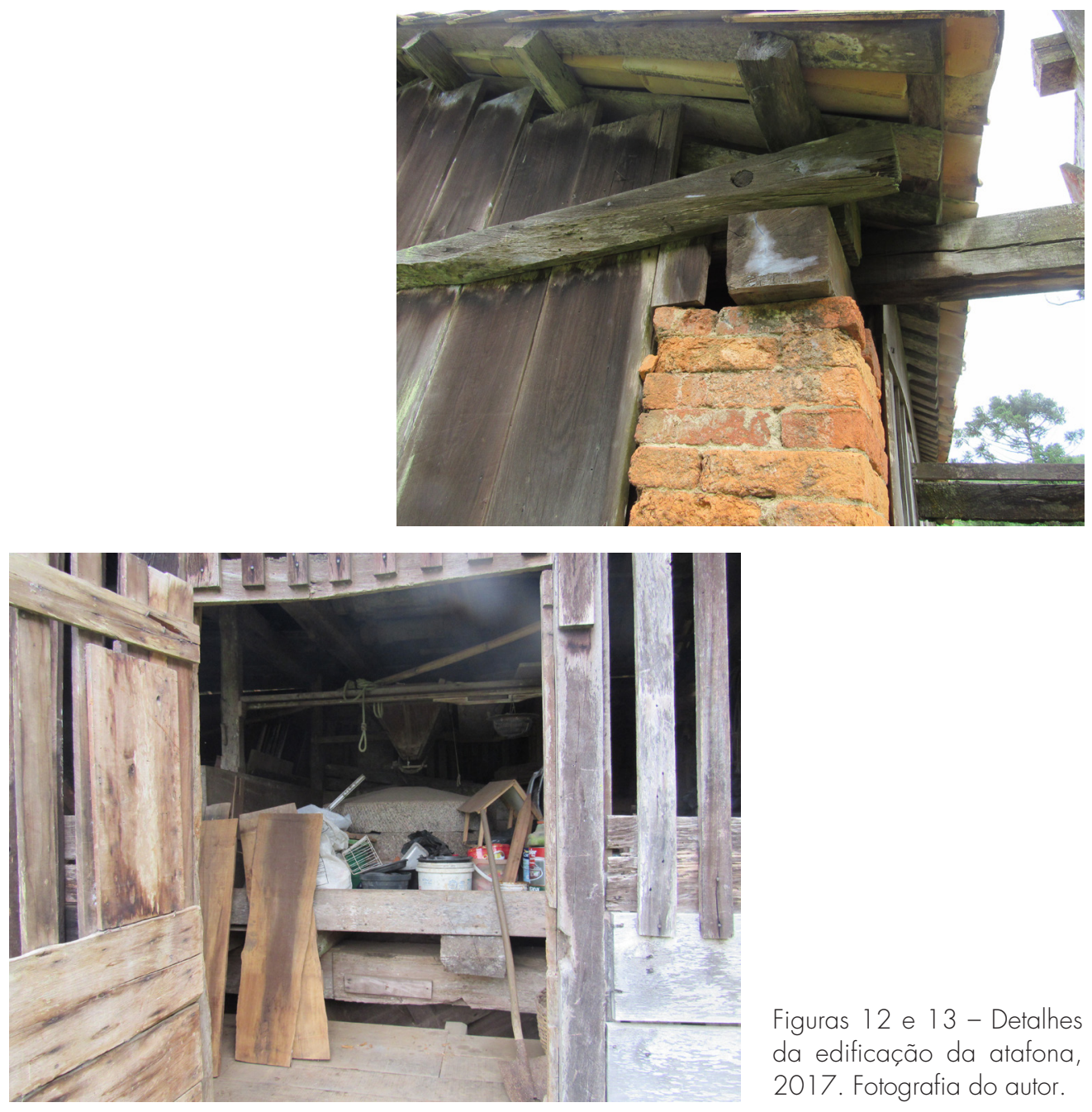

Figuras 12 e 13 - Detalhes da edificação da atafona, 2017. Fotografia do autor.

trabalhadores expresso em sua materialidade. Tal testemunho revelaria, principalmente, o espírito, o pensamento, o trabalho e o coração de cada trabalhador envolvido em sua edificação. Entretanto, a matéria da arquitetura seria finita, assim como a vida humana. Mesmo conservando e preservando, quando o seu dia final chegasse, ela deveria ser lembrada pelo que realmente foi e não por uma "mentira em seu lugar". 42

Para Ruskin, a admiração que sentimos pela beleza acidental ou pitoresca demonstrada na arquitetura parece estar intimamente ligada ao inesperado e às incertezas da ação do tempo provocadas sobre a matéria. Tais incertezas também perturbariam a nossa observação formal, deslocando-a para além das características essenciais da coisa representada e emprestando certa rusticidade ao corpo arquitetônico. Dessa forma, pode-se dizer que haveria uma relação 
entre a beleza pitoresca e as imperfeições que se formam no corpo arquitetônico. E essa beleza pitoresca, que desgasta a matéria e intensifica os pontos de sombra de uma edificação, estaria, também, de alguma forma, ligada ao fantástico paradoxo ruskiniano. Ao escolher a matéria do edifício e ao conceder maior ou menor permanência da ação do tempo sobre ela, o arquiteto ou o artesão permitiriam certas irregularidades positivas em sua edificação, reveladas pela vida que também se manifesta na matéria viva. Nesse sentido, o fantástico paradoxo tanto se revelaria na beleza das debilidades e das imperfeições inerentes ao trabalho humano vivo quanto se manifestaria nas irregularidades provocadas pelo tempo vivido pela matéria edificada. Contudo, cabe ressaltar que, embora a beleza pitoresca se mostre quando transforma a superfície da matéria, o seu encantamento não consistiria no apreço à deterioração ou à precariedade. De acordo com Ruskin, a beleza que se forma pelas imperfeições derivadas da ação do tempo sobre a matéria seria agradável aos nossos olhos, sobretudo, porque tais imperfeições assemelham a arquitetura à obra da Natureza e the confeririam certas particularidades em sua aparência que seriam estimadas pela maioria dos homens. ${ }^{43}$

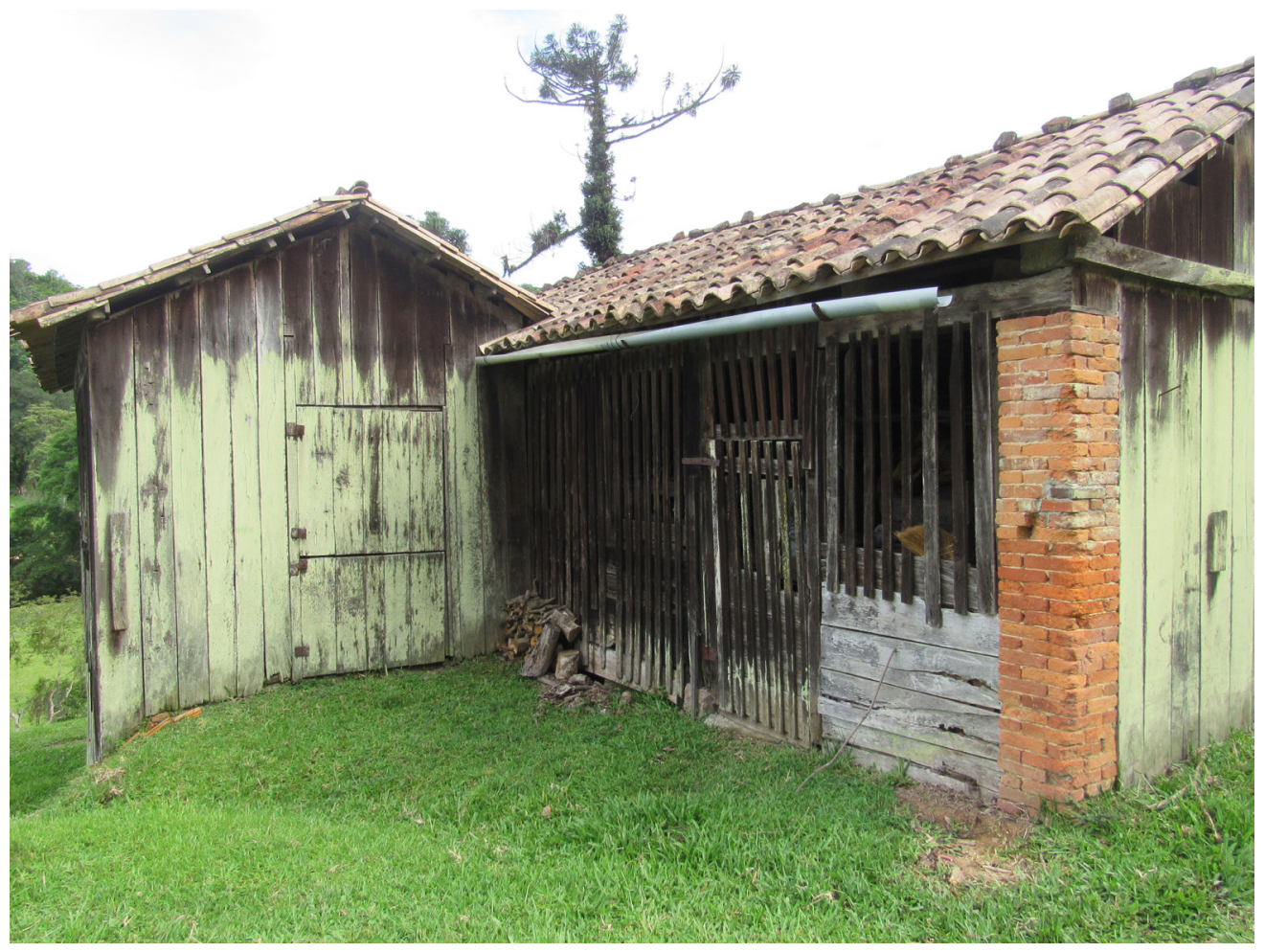

Figura 14 - Fundos da edificação da ałafona, 2017. Fotografia do autor. 


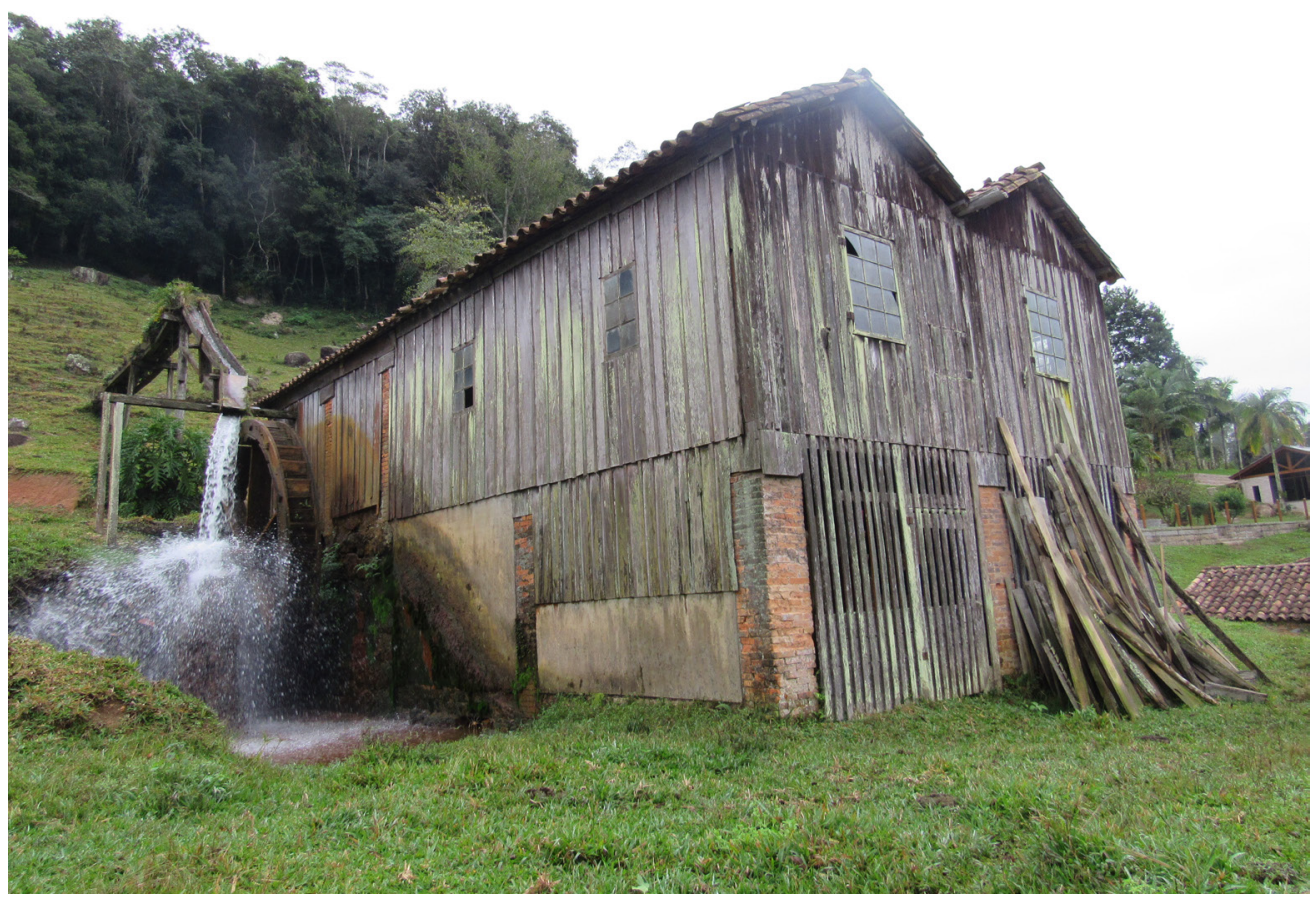

Figura 15 - Edifício da atafona [a], 2017. Fotografia do autor.

No entanto, para o autor, no momento em que a manifestação da vida, demonstrada, principalmente, pelas imperfeições positivas, foi sendo expulsa da arte, no momento em que a simplicidade e a rusticidade, a fantasia e a invenção, os mistérios e os devaneios foram sendo excluídos do fazer artístico, a beleza na arquitetura foi igualmente sendo destruída. Ao perder uma de suas principais "fontes de prazer" - os ornamentos, os arranjos e as saudáveis invenções provindas da Natureza -, a arquitetura acabou perdendo, igualmente, a sua vitalidade. Se, antes, artistas e artesãos se voltavam para a Natureza, como obra máxima da criação divina, para se alimentar de suas formas e cores ao mesmo tempo em que davam corpo às suas representações, agora estavam expostos à monotonia das formas modernas. De acordo com Ruskin, "[...] em qualquer parte nenhum prazer é alcançado nas construções modernas e encontramos todos os homens de sentimento verdadeiro deleitando-se em escapar das cidades modernas para o cenário natural". Daí, o "amor à paisagem característico do século". ${ }^{44}$ Se, antes, o amor pela Natureza era característica essencial do cristianismo e encontrava alimento sobretudo na arquitetura gótica, agora via-se sem fonte de expressão e de sustento. A escola pitoresca da arte teria surgido, de acordo com o autor, para ressuscitar aquelas
44. Ruskin (1904, v. II, p. 207, tradução nossa). No original: "[...] no pleasure is taken anywhere in modern buildings, and we find all men of true feeling delighting to escape out of modern cities into natural scenery: hence, as I shall hereafter show, that peculiar love of landscape, which is characteristic of the age". 
45. Segundo Townsend (1951, p. 59-82), a grande preocupação de Ruskin, desde as primeiras obras, era melhorar o espírito da humanidade, e ele teria se concentrado no fenômeno estético do seu tempo - the landscape feeling - como um meio de desenvolvimento moral. Contudo, na medida em que começava a aflorar, em Ruskin, uma maior consciência dos males sociais, este sentimento de paisagem foi reduzido em suas obras após 1855. Pois, apesar da percepção do que é belo na arte e na natureza estivesse, de alguma forma, ligada ao que é correto nas ações práticas da vida humana, isso não parecia melhorar o desenvolvimento dos deveres morais nos homens. Para Townsend, este seria o "ponto de virada" da carreira de Ruskin. No momento em que Ruskin percebeu que o sentimento de paisagem era mais um "efeito do que uma causa do fenômeno social", ele teria se voltado para os assuntos de economia política.

46. Ruskin (1904, v. III, p. 226, tradução nossa). No original: "And thus the English school of landscape, culminating inTurner, is in reality nothing else than a bealthy effort to fill the void which the destruction of Gothic architecture has left."

47. Ruskin (1904, v. III, p. 226).

48. Ruskin (1904, v. III, p. 226, tradução nossa). No original: "No form of art answers these conditions so well as architecture."

49. Ruskin (1904, v. III, p. 226).

50. Ruskin (1904, v. III, p. 226, tradução nossa). No original: "Pictures and statues may be jealously faculdades de prazer que já não estavam mais sendo alimentadas pelas práticas artísticas cotidianas. E "a Escola Inglesa de paisagem, culminando em Turner", 45 seria, na realidade, "nada mais do que um esforço saudável para preencher o vazio que a destruição da arquitetura gótica tinha deixado". 46

No entanto, a pintura de paisagem nunca despertaria interesse suficiente, segundo Ruskin, para atrair a mente dos homens que se preocupam com os assuntos práticos da vida cotidiana. De modo que, tais homens - e estes representariam a maior parte deles - somente seriam envolvidos por uma "arte direta e substancial", pública e partilhada, produzida para a contemplação diária porque constituinte da paisagem cotidiana e, principalmente, relacionada com os interesses que se formam diante dos assuntos da vida. ${ }^{47} \mathrm{E}$ "nenhuma forma de arte responde[ria] a estas condições tão bem quanto a arquitetura". ${ }^{48} \mathrm{~A}$ agitação e o aglomerado da vida urbana, a que várias pessoas estavam sendo expostas nas cidades do século XIX, somente poderia ser diminuída, segundo ele, pela influência que o "poder da arquitetura antiga" ainda exerceria sobre nós, ao tomar o lugar que a influência da Natureza - das florestas, dos campos, da paisagem natural - tinha sobre os homens, principalmente sobre os artistas e os artesãos. Para Ruskin, a arquitetura seria a única arte social que poderia preencher o vazio que a vida urbana e industrial havia promovido na convivência cotidiana. E, principalmente, por ser uma arte compartilhada, ela poderia receber a influência do trabalho, do pensamento e do coração de cada trabalhador nela envolvido. Da mesma maneira, ela poderia falar diretamente com cada um daqueles que fossem usufruir daquela obra, uma vez que a arquitetura seria, sobretudo, "propriedade de todos os homens". ${ }^{49}$ Enquanto a pintura e a escultura poderiam ficar fora do alcance da massa de homens comuns, a arquitetura era pública: "[...] o exterior de nossas casas pertence não tanto à nós como ao transeunte, e qualquer que sejam os custos ou as dores que nós conferimos a elas, embora muitas vezes decorrentes de ostentação, tem pelo menos o efeito da benevolência". 50

Se a natureza dos materiais pode influenciar na formação da beleza pitoresca, perceber a arquitetura rural pelo fantástico paradoxo da imperfeição, principalmente as edificações em madeira, pode nos ajudar a compreender essa materialidade pelas relações que se formam entre as imperfeições que caracterizam a natureza da própria madeira, pelas imperfeições que se formam com a ação do tempo, e pelas imperfeições que registram a presença mesma da ação do artesão. Para além das necessidades inerentes à sua construção primeira, a verdade construtiva tanto dos engenhos quanto dos edifícios do conjunto Bez Fontana parece revelar, de alguma maneira, a expressão do pensamento empregado na sua fatura. A imperfeição na edificação se manifestaria não somente na rudeza de seus 
acabamentos, mas nos arranjos construtivos e compositivos, que evidenciariam o pensamento que inventa e se conforma, da mesma maneira que orienta as mãos que o executam. Tais arranjos construtivos demonstrariam as escolhas do artífice construtor, o seu conhecimento técnico, as suas habilidades e a sua inventividade.

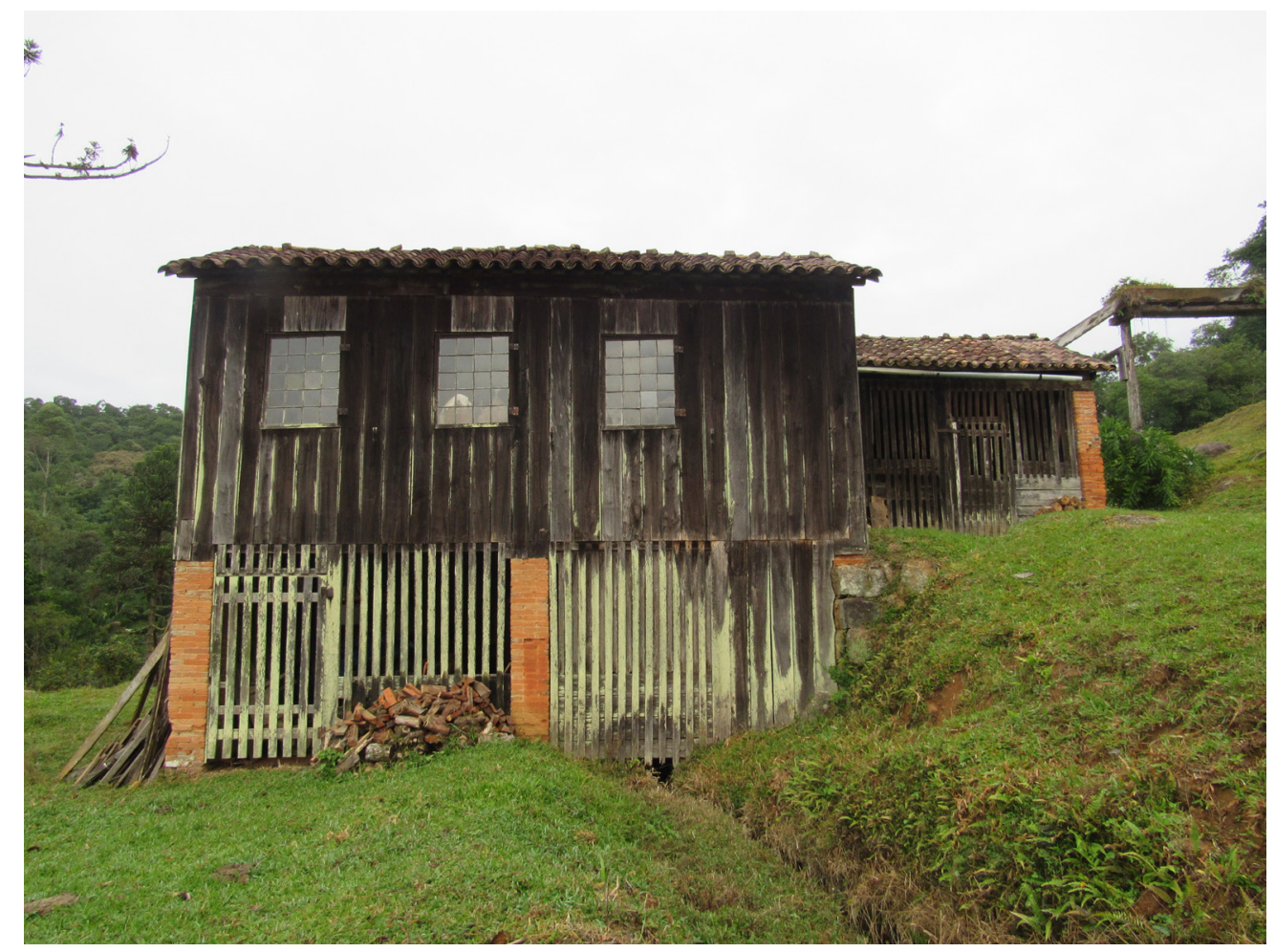

Figura 16 - Edifício da atafona [b], 2017. Fotografia do autor.

$\bigcirc$ corpo do edifício da atafona não reflete requintes formais. $\bigcirc$ tabuado de madeira, intercalado em algumas partes por tábuas tipo mata-junta, evidencia as linhas simples e justas da edificação. A materialidade da madeira guarda, como uma de suas características mais singulares, uma certa maleabilidade que the permite entregar-se à ação do tempo, da chuva, do calor e da umidade. Em seus longos anos de vida, o edifício da atafona recebeu a inevitável presença do tempo. Talvez pelos diferentes tipos de madeira de que o edifício deve ser constituído, talvez por sua posição no sítio que determina o momento em que ele é tomado pela luz do sol, a madeira assume várias colorações - desde um tom cinzento mais claro até tonalidades bem escuras -, dialogando com a aparência das pedras e das cascas das árvores. Na fachada que guarda a roda-d'água, as marcas da ação da água na parede lateral do edifício concedem igualmente à madeira uma aparência modificada. As pedras que formam a terça parte da parede do piso withdrawn by their possessors from the public gaze, and to a certain degree their safety requires them to be so withdrawn; but the outsides of our bouses belong not so much to $u$ s as to the passer-by, and whatever cost and pains we bestow upon them, though too often arising out of ostentation, have at least the effect of benevolence." 
inferior da atafona também são modificadas pela ação do tempo e do fluxo de água, com a formação de uma cobertura irregular de um intenso musgo verde (figura 15). O efeito pitoresco que se forma por tais marcas e que também revela a longa idade do edifício demonstra uma beleza que despretensiosamente se forma na camada mais superficial da matéria e que aproxima, de alguma maneira, a edificação ao cenário que a envolve. $\bigcirc$ corpo do edifício da atafona se ergue ao pé do morro, mas não o ignora - um não ofende o outro -, e, assim, numa relação quase solidária e fraterna, a arquitetura se acomoda às irregularidades do sítio, ao mesmo tempo que se deixa invadir pela afortunada presença da natureza e pela ação do tempo. Essa relação fraterna entre a arquitetura e a paisagem fica evidente em todos os edifícios que compõem o conjunto Bez Fontana, na medida em que se ajustam aos desalinhos e às irregularidades do relevo.

A construção é formada por dois corpos gêmeos demonstrados principalmente pelo conjunto do telhado erguido numa dupla composição de águas. Os dois corpos, lado a lado, formam o volume principal do edifício que é suavizado pelos dois pequenos telhados e pelas duas delicadas janelas colocadas na fachada. Um dos corpos se prolonga mais que o outro, na parte de trás da edificação, formando uma pequena sobreposição, quando avistado da entrada principal da propriedade. $O$ tabuado de madeira que dá forma ao corpo do edifício (figuras 14, 15 e 16), os encaixes feitos com cavilhas de madeira na parte final da tesoura do telhado que se apoia no frechal (figura 12), as misturas e as irregularidades provocadas pelas pequenas tábuas horizontais colocadas numa parte e noutra da construção (figuras 13 e 14) testemunham a expressão do trabalho do artífice na constituição da edificação, da mesma forma que manifestam suas necessidades e intenções construtivas através do tempo.

Um pouco à frente do edifício da atafona, caminhando em direção ao norte, o observador se depara com parte do telhado do edifício da marcenaria que se aninha aos seus pés (figura 17). A inversão das alturas, provocada sobretudo pela edificação que se acomoda aos declives da topografia e pelo telhado que parece repousar no solo do terreno, nos coloca como que diante de algo fantasioso. Acompanhando o telhado de duas águas, o corpo da edificação vai tomando forma, aos poucos, até compor o volume total do edifício, igualmente formado por um tabuado irregular. $\bigcirc$ edifício é constituído por três ambientes. $\bigcirc$ porão da edificação acomoda todo o sistema de transmissão de energia da roda-d'água. $\bigcirc$ chão de terra batida divide o espaço com duas imensas pedras, que compõem o cenário natural, ao mesmo tempo que resguarda a presença humana revelada nos barrotes e nos esteios que sustentam a edificação (figuras 9 e 10). Ali dentro, o barulho da água, que cai desviada ao lado da roda-d'água, é ainda mais intenso 
do que quando anunciado do lado de fora da edificação. Acima do porão, no piso térreo, funcionava a serraria, que guarda a aparência de um galpão, aberto numa das fachadas, facilitando, na época, a entrada e o beneficiamento da madeira bruta. Acima da serraria funciona a marcenaria e o corpo desse edifício se estende, elevando-se sobre boa parte da serraria.

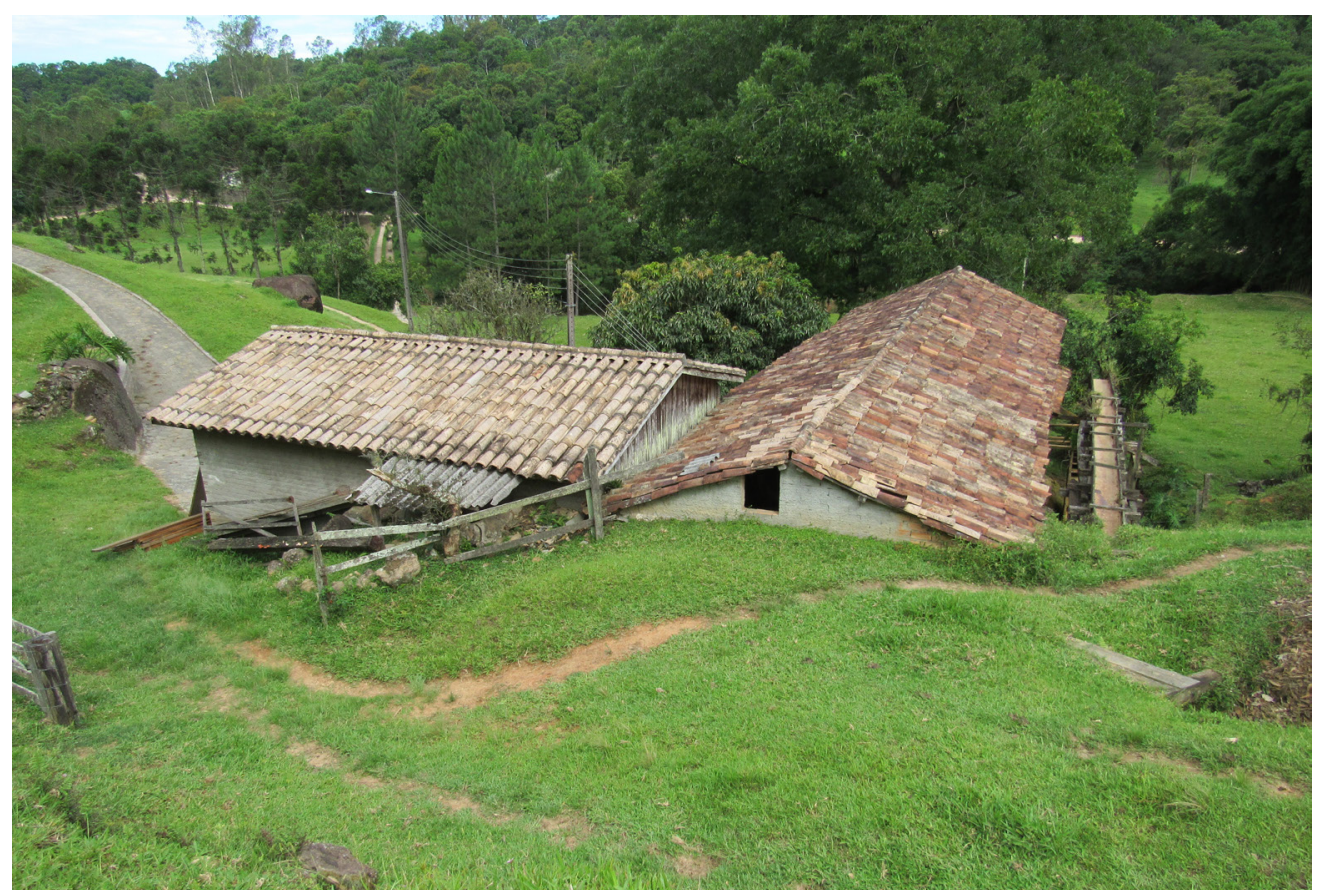

Figura 17 - Edifício da marcenaria, detalhe do telhado, 2017. Fotografia do autor.

Ao entrar na marcenaria, a fantasia ${ }^{51}$ antes anunciada pelo inusitado dos telhados, que pareciam surgir do chão, agora se consuma. Para um olhar alheio, que descobre este lugar pela primeira vez, o ambiente se desvela num lugar fantástico, que carrega em sua composição um aglomerado de camadas, de vestígios e de rastros, de materiais de outrora, perdidos e reencontrados a cada dia. Além disso, o barulho da queda-d'água que alimentava a roda nos concede uma agradável sonoridade, agora bem menos intensa do que a presenciada no porão da edificação. Várias peças e moldes pendurados no correr das paredes internas, bem como alguns pedaços de madeira encostados nos cantos, se iluminam pela generosa luz que entra pelas janelas feitas em louro (figura 20). Além dos moldes e das peças executadas de outras épocas, as ferramentas artesanais dividem o espaço com as máquinas elétricas. No interior da edificação, a fantasia e a imaginação do artífice tomam corpo na matéria por ele fabricada. As diversas formas ali realizadas anunciam o espaço da marcenaria como uma grande fábrica
51. Numa palestra intitulada "Influência da imaginação na arquitetura", proferida aos membros do Architectural Association, em Lion, em 1857, Ruskin declarava que o trabalho de um arquiteto, além de envolver um bom desenho, a observação e a precisão aritmética na execução das estruturas, deveria, de alguma maneira, nos contar uma história encantada por ele inventada, senão não poderíamos elogiá-lo por sua imaginação. Ruskin (1905, p. 347). 
52. Posenato (1983, p. 122).

53. Quando emigraram, Giacomo Bez Fontana e a esposa Cattarina de Bona tinham 41 anos de idade, e os filhos Giovani, 14 anos, Luigi, 12 anos, Antônia, 10 anos, Antônio, 8 anos, e Maria, 5 anos. Sebastião, com 16 anos, estava servindo o exército que, na época, tinha a duração de quatro anos. Entretanto, por volta de 1881, ele viria junto com mais uma leva de imigrantes, mesmo sem cumprir o serviço militar. Além do casal e dos filhos, a mãe de Giacomo, Antônia de Bona, então com 71 anos, também veio para o Brasil. Fontana (1998, p. 2125). Germano Bez Fontana é neto de Sebastião Bez Fontana e, ainda em vida, publicou este livro que traz, além de muitas informações sobre a família do avô, relatos sobre o seu percurso e sobre a sua história pessoal.

54. Sebastião Bez Fontana casou-se, em 1883, em Urussanga, com Giovanna Tramontin. O casal teve sete filhos, duas mulheres $\mathrm{e}$ cinco homens: Giacomo, Catarina, Ângelo, João, José, Rafael e Elizabete. Fontana (1998, p. 24) inventiva, que ainda hoje conjuga pequenos processos artesanais com uma maquinaria mais moderna. A vitalidade do ofício dos artífices manifestada na edificação pode ser observada na manufatura de algumas peças falquejadas, que compõem o telhado da marcenaria, e em alguns barrotes, que formam o teto da serraria (figuras 21 e 22). Segundo Posenato, o falquejo era utilizado, normalmente, em peças maiores como pilares, vigas e barrotes, desbastando a tora com um machado. ${ }^{52}$ Ao falquejar, para tornar quadrado o tronco da madeira, o artesão deixa inscrito na matéria a imprecisão e a intenção de seus golpes. A variedade e a imperfeição daí decorrentes anunciam a beleza do labor humano, ao mesmo tempo em que revelam, em sua irregularidade constante, certa homogeneidade à forma pretendida. Da mesma maneira, as ferramentas tradicionais também guardam a presença do trabalho do artífice, tanto nas pequenas variações do gesto humano quanto na habilidade técnica necessária à sua fabricação.

Considerando o tempo vivido pelo conjunto Bez Fontana, as camadas que se formam na superfície da matéria bruta dos edifícios que constituem a atafona e a marcenaria parecem ser alimentadas pelas camadas temporais que constituem a história mesma desse corpo ancião. Esses volumes centenários guardariam, em sua materialidade, a presença inscrita de todos os artífices da família - seja daqueles que ergueram a construção primeira, seja daqueles que a preservaram. Da mesma maneira, tais volumes também se manifestam como uma substância ativa, em parte revelada pela natureza mesma da madeira, em parte revelada pelo trabalho dos artesãos envolvidos em sua edificação, ao considerar a natureza circundante também como constituinte do corpo arquitetônico que se formava. Assim, se os elementos pitorescos da arquitetura, que se mostram nas camadas superficiais e visíveis do edifício, the conferem beleza, o mesmo efeito se dá com as camadas aparentemente ocultas de sua história.

\section{A VIDA E O TRABALHO DO ARTÍFICE}

Segundo os relatos da família, o imigrante Giacomo Bez Fontana deixou a região de Longarone, província de Belluno, na ltália, em direção ao Brasil, por volta de 1879, com sua esposa e cinco dos seis filhos. $\bigcirc$ filho mais velho do casal, Sebastião Bez Fontana, na ocasião, estava em serviço militar ${ }^{53}$ e viria dois anos depois. Os conhecimentos em relação ao trabalho com a madeira que Giacomo Bez Fontana resguardava foram transmitidos aos filhos, e Sebastião Bez Fontana, ${ }^{54}$ por volta de 1901, colocou em atividade uma serraria, uma carpintaria e uma 
marcenaria. $\bigcirc$ espírito laborioso de Sebastião pode ser percebido tanto nas atividades em suas indústrias ${ }^{55}$ quanto nos cargos em que cumpriu atividades comuns no município - fora nomeado subcomissário de polícia do distrito, em 1891, e atuou como conselheiro municipal por alguns anos, quando Urussanga se tornou município. De acordo com o relato do neto, Germano Bez Fontana, depois que uma enchente, por volta de 1913, destruiu, pela segunda vez, uma atafona numa localidade conhecida como Núcleo Treze de Maio, o seu avô, atendendo aos pedidos dos colonos daquela região, resolveu reconstruíla. Comprou as pedras do antigo proprietário e, com a ajuda dos filhos, construiu, além de uma atafona, uma serraria e uma marcenaria, nas terras que havia comprado anos antes, em 1911, formando um complexo de indústrias parecido com o que ele tinha em Urussanga, igualmente movido à roda-d'água. Ainda de acordo com o relato de Germano, o avô teria feito um inventário em vida, deixando cada filho com uma indústria, sendo que a atafona, a serraria e a marcenaria de Urussanga ficaram para os irmãos João, Ângelo e Rafael Bez Fontana. ${ }^{56}$ É possível perceber, pela narrativa de Germano, que a família Bez Fontana é formada por vários artífices que se dedicaram ao trabalho com a madeira. Contudo, vamos nos manter na linha sucessiva daqueles que permaneceram no conjunto tombado e que mantiveram em funcionamento a carpintaria, a serraria e, principalmente, a marcenaria de Sebastião Bez Fontana.

Bisneto de Sebastião, Olclésio Bez Fontana ${ }^{57}$ é a quinta geração de artífices da família, e acredita que esse saber-fazer geracional do ofício talvez tenha influenciado a sua escolha de trabalho. $\bigcirc$ fato de o ofício e as indústrias estarem localizados no mesmo sítio onde está situada a casa da família torna, também, tanto a artesania do artífice quanto as próprias edificações muito mais próximas daqueles que convivem com essa materialidade. Desde criança, Olclésio já percorria o ambiente das indústrias do seu bisavô, mas como uma forma de brincadeira. Seu pai, Galdino Bez Fontana, ${ }^{58}$ sempre trabalhou sozinho e, com mais ou menos quinze anos, Olclésio começou a trabalhar na marcenaria ajudando o pai. Hoje, além de ser um marceneiro reconhecido na região pelo seu trabalho pessoal, é também reconhecido pela história que a sua família guarda em relação ao ofício com a madeira.

Os filhos de Sebastião, de acordo com a narrativa de Olclésio, trabalhavam todos juntos, nas atividades das indústrias do pai. No piso térreo da marcenaria, uns trabalhavam serrando as toras de madeira e, na parte de cima, outros trabalhavam no beneficiamento, fazendo aberturas - portas e janelas - e móveis. Não é possível precisar se esta separação representava uma necessidade de racionalização do trabalho pela divisão de funções ou se havia alguma intenção
55. A família guarda, na parede de uma das salas, um certificado que confere medalha de prata à Sebastião Bez Fontana por sua participação na Exposição Nacional de 1908, em comemoração ao centenário da abertura dos portos no Brasil, realizada na cidade do Rio de Janeiro. Mantendo o mesmo espírito das Exposições Universais, das quais o Brasil já havia participado em algumas edições, a Exposição Nacional de 1908 foi uma das mais importantes realizadas no país, e a participação de Sebastião demonstraria o trabalho idealizador desse artífice. Além disso, Sebastião também foi fotógrafo na cidade. A família ainda guarda vários negativos de cristal de fotos feitas pelo artesão, bem como o Diploma di Benemerenza em reconhecimento e homenagem ao primeiro fotógrafo da cidade de Urussanga.

56. Ainda de acordo com Germano, o avô teria feito o inventário em 1919. Giacomo Bez Fontana, pai de Germano, ficou com dois lotes de terra e a serraria; José Bez Fontana ficou com dois lotes de terra, a marcenaria e a atafona; e Pio Trento, casado com Catarina Bez Fontana, ficou com dois lotes de terra. Essas terras formavam os lotes adquiridos em 1911, acima mencionado. Fontana (1998, p. 48-50).

57. Olclésio Bez Fontana é um dos mestres artífices relacionados no inventário feito pelo IPHAN, em 2012, com o objetivo de reconhecer os artesãos que ainda mantêm um saberfazer de técnicas construtivas tradicionais. Para conhecer a relação dos ofícios e dos artesãos catalogados, cf. Mestres Artífices Santa Catarina: cadernos de memória. A entrevista com 
Olclésio foi feita em sua casa, na cidade de Urussanga, no dia 20 de fevereiro de 2017. Depois disso, houve mais uma conversa realizada no dia 18 de maio de 2017, além de mais duas visitas para fotografar o conjunto dos bens tombados.

58. Galdino Bez Fontana é filho de Rafael Bez Fontana e neto de Sebastião. Casouse com Olga Gastaldon e tiveram sete filhos: Olvacir, Oldagé, Olnesi, Olnete, Olvenita, Olvilene e Olclésio. Fontana (1998, p. 35). em estabelecer uma produção fabril assentada nas relações de trabalho cooperado. A fragilidade dos relatos e das memórias familiares não nos permite evidenciar o que impulsionava tais relações de trabalho. Sabe-se, entretanto, que Olclésio trabalha, na maior parte do tempo, sozinho, assim como seu pai também trabalhava. Salvo nos trabalhos ocasionais em que recebe a ajuda de outro marceneiro para atender à alguma encomenda de marcenaria padronizada, o trabalho ocorre de forma solitária. Além disso, há uma relação particular que se estabelece no contato entre este artesão e a madeira. Para Olclésio, diferentemente de um trabalho feito em marcenaria planejada, somente o trabalho feito em madeira the possibilitaria maior liberdade criativa, uma vez que, a matéria viva da madeira, em função de sua natureza, the permitiria maiores possibilidades de execução.

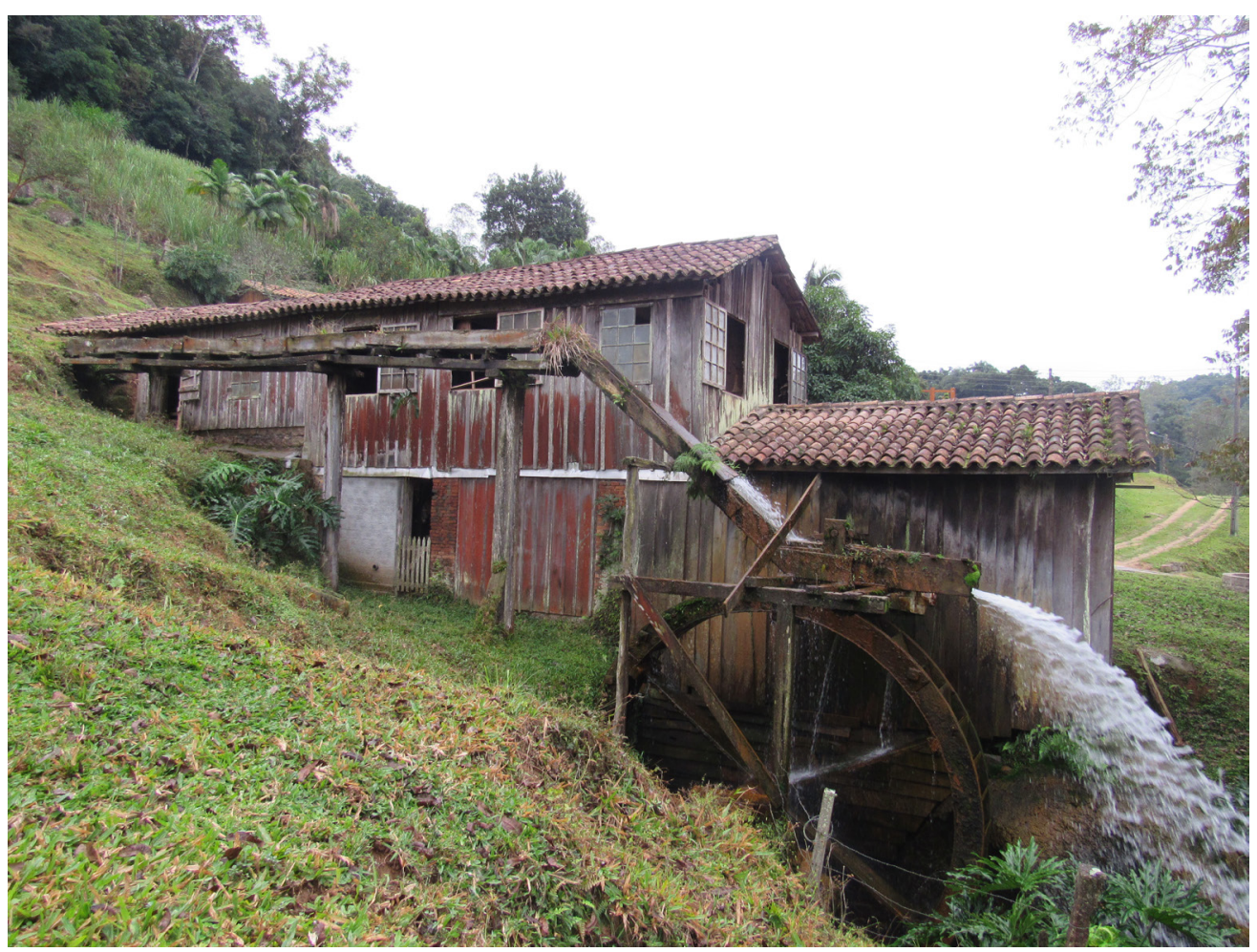

Figura 18 - Edifício da marcenaria, 2017. Fotografia do autor.

Nos primeiros anos de funcionamento da marcenaria, segundo Olclésio, os tipos de madeira mais utilizados eram a canela, a peroba, o cedro e o louro. A peroba é um tipo de madeira mais adequado para partes internas, de acordo com o marceneiro, enquanto a canela, o cedro e o louro são madeiras que se prestam para quase tudo, tanto para a área externa quanto para a área interna de 
uma edificação. Além dessas, tem-se o sobraji que, também segundo esse artesão, seria a "rainha das madeiras", por sua resistência e durabilidade. ${ }^{59}$

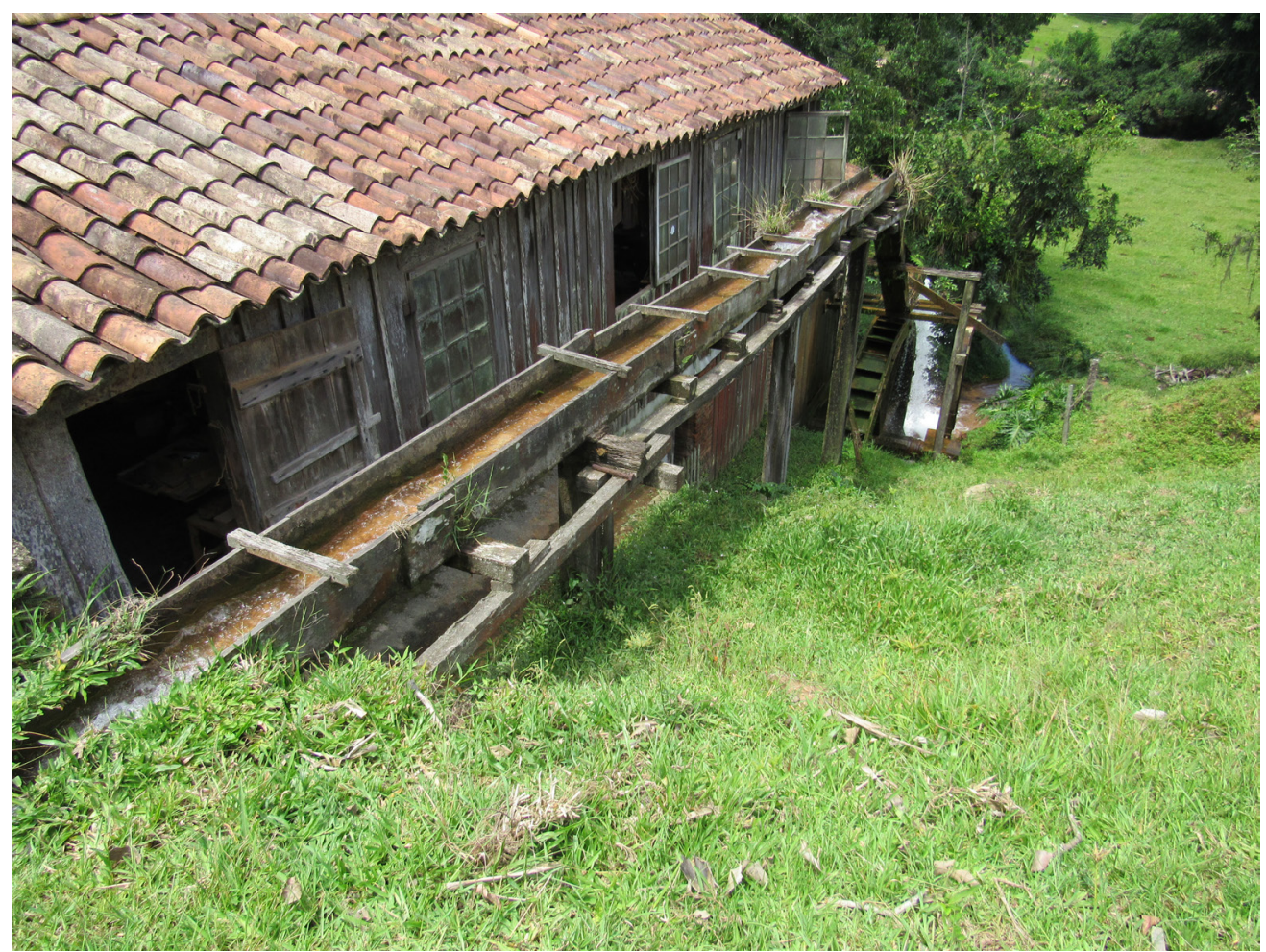

Figura 19 - Parte lateral do edifício da marcenaria, 2017. Fotografia do autor.

Na marcenaria ainda estão guardadas algumas ferramentas e moldes utilizados por Sebastião, inclusive peças manufaturadas por ele mesmo que, naquela época, tinha que se deslocar até a cidade de Laguna para comprar ferro, a fim de produzir utensílios que o ajudassem no seu ofício. Olclésio fala com admiração de um móvel feito pelo seu bisavô que, mesmo sem os equipamentos e as máquinas que se tem hoje, conseguiu fazê-lo com excelente acabamento (figura 27). Hoje, apesar de utilizar ferramentas elétricas que the dão, além de maior precisão e rapidez, melhor acabamento, o processo da fatura dos objetos, segundo Olclésio, ainda guarda proximidade com o saber-fazer transmitido por gerações: "tem coisas que eu aprendi com meu pai que eu trago até hoje". Entretanto, mesmo que parte da técnica e das formas de fazer tenha se mantido inalterada, existiriam algumas diferenças, de acordo com Olclésio, entre o seu trabalho e o trabalho de cada geração de artífices da sua família que conferem certas particularidades ao ofício de cada um. Os meios do seu aprendizado foram a observação e a repetição. Seu pai, Galdino, the ensinava como deveria ser feito, mas seria,
59. Segundo as memórias do padre Marzano (1985, p. 120), ao analisar as madeiras existentes na Colônia Urussanga, ele também elegia, em primeiro lugar o sobraji. "É a mais resistente de todas, e depois de anos parece de ferro. Os colonos usam desta madeira para formar os quatro ângulos da casa e também para fazer cercas de estaquetes". 
60. Ruskin (2004, p. 72-73), edição em português. No original: "Thus the science of nations is to be accumulative from father to son: each learning a little more and a little more; each receiving all that was known, and adding its own gain [...] and the art of nations is to be accumulative, just as science and history are; the work of living men is not superseding, but building itself upon the work of the past." Ruskin (1905, p. 6364). sobretudo, pela repetição e pela prática que o ofício ia se fazendo, à medida que o artesão ia tomando posse do saber. E essa relação entre o saber e o fazer que toma corpo pela observação e pela repetição demonstraria que o fazer de novo também poderia revelar-se num ato criativo. A repetição também poderia ser criadora, na medida em que cada artesão, de cada geração, ao receber o ofício geracional, tanto resguarda e mantém parte dos saberes por ele evidenciados quanto coloca a sua própria colaboração no ofício recebido. Segundo Ruskin, "a ciência das nações é cumulativa, de pai para filho [...] cada um recebendo tudo que se sabe e acrescentando sua própria contribuição". Da mesma forma, "a arte das nações também é cumulativa [...]; o trabalho dos vivos não supera o trabalho do passado, mas se ergue sobre ele". 60

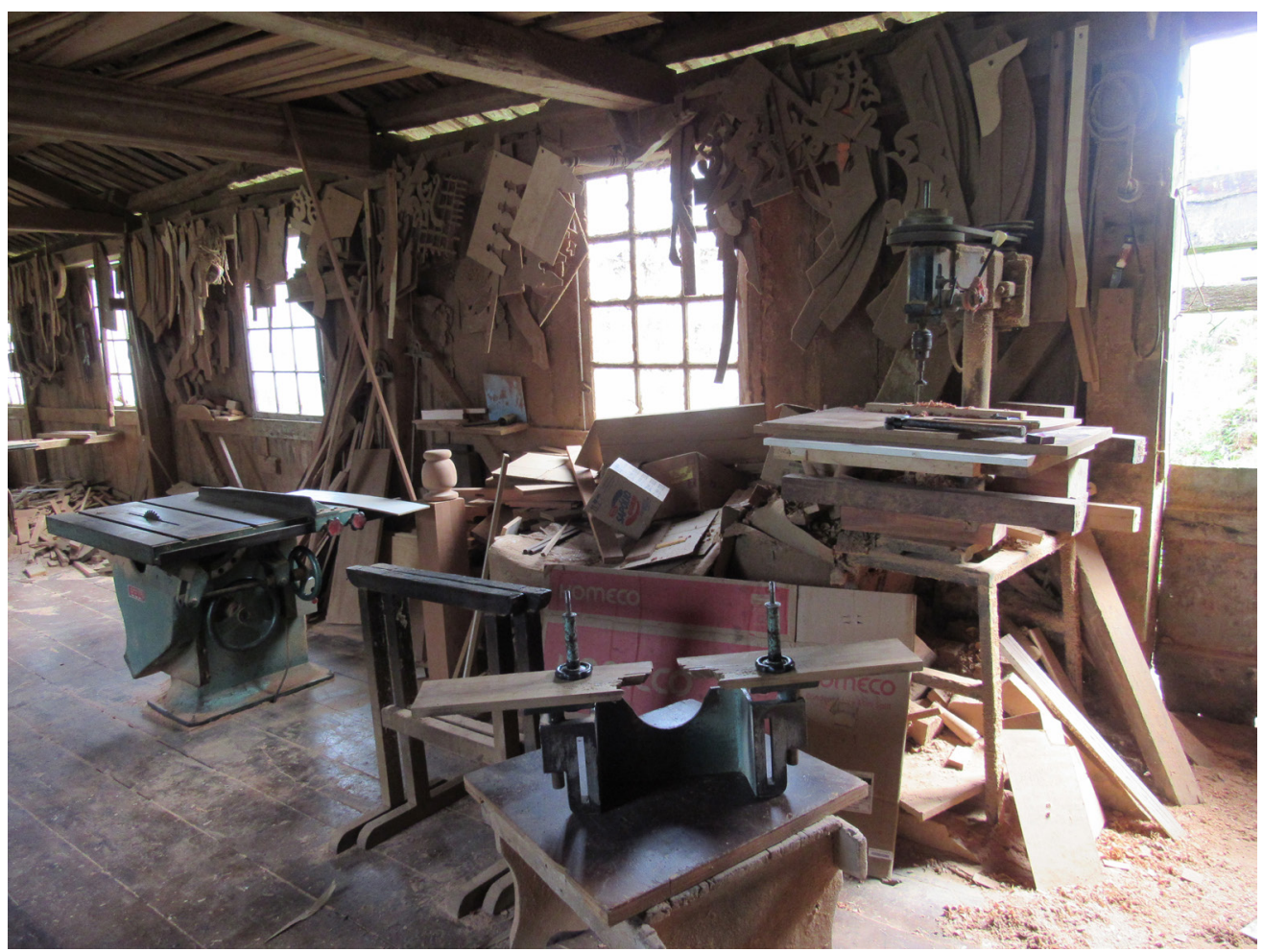

Figura 20 - Interior da marcenaria. Detalhe dos moldes antigos, 2017. Fotografia do autor.

O trabalho de Olclésio começa com a escolha da madeira que se dá, depois de cortada, pelo reconhecimento do cheiro, da cor e dos veios. A escolha da madeira é fundamental para que o trabalho seja bem-feito, pois cada uma demonstraria certas particularidades que definiriam o que seria possível fazer, além de orientar a forma com que o marceneiro deveria lidar com ela em seu ofício. Uma conversa íntima e silenciosa parece, então, se estabelecer a partir de um encontro 
fraterno entre o artesão e o material. Esse encontro manifesta-se, sobretudo, pelo respeito revelado pelo aríífice em relação à madeira enquanto matéria viva que, além de guardar características particulares, demonstraria em sua superfície os sinais e os vestígios que servem de orientação ao trabalho do artesão. Sua habilidade, tanto executiva quanto inventiva, dependeria, em maior ou menor grau, dessa relação particular com a natureza mesma de cada madeira. E esse encontro mostra-se tão vivo que, mesmo que o artesão vá trabalhar uma vida inteira com aquele material, esse reconhecimento inicial se repete e se mantém a cada novo encontro.

No trabalho com a madeira, os saberes tradicionais são, antes de tudo, uma prática relacional em que o conhecimento se consolida a partir da comunhão entre a matéria e o artesão. Esse vínculo entre os dois corpos, tanto do artífice que coloca a presença do seu trabalho e do seu pensamento na transformação do material quanto da madeira que proporciona a matéria para o engenho do artesão, manifesta o fantástico paradoxo que constitui tal relação. A vida que se manifesta no gesto animado do artesão revela-se tanto no trabalho de imaginação do artífice - ao tentar dar a forma que convém ao material - quanto na aceitação de suas particularidades e limitações. E essa relação corporal entre o artesão e a matéria, na fatura do seu ofício, se mostraria, sobretudo, pelo uso das mãos conduzidas pelo pensamento. De acordo com Ruskin, uma das piores manifestações da sociedade moderna repousava na concepção que se tem das "atividades oficinais como sendo de caráter inferior e pouco nobre". ${ }^{61}$ A noção de que o trabalho manual degradaria $\circ$ intelecto, assim como a percepção moderna de que o pensamento de um homem deveria ser executado pelas mãos de outro, seria, segundo o autor, o resultado da regressão de toda a indústria do homem do século XIX. Pois seria justamente a falta de trabalho humano e de vida pulsante que tornaria a coisa produzida vulgar e sem valor.

Olclésio é um dos únicos marceneiros da região que ainda faz uso do torno. Dentre todos os equipamentos utilizados por ele, o torno parece ser aquele que exige do artesão, de uma só vez, tanto a habilidade manual quanto a capacidade de raciocínio abstrato. Requer do artífice tanto o envolvimento corporal - nos momentos de pressão e alívio da ferramenta - quanto o intelectual - ao raciocinar e conduzir a mão enquanto a madeira gira incessantemente. Evidenciase uma necessária sincronia entre o movimento corporal do artesão e o raciocínio abstrato que the é exigido ao modelar a madeira no torno, uma vez que não é somente a forma que está por vir e que se esconde na matéria bruta, mas a madeira em si que ganha outra forma com o movimento contínuo do torno, requerendo do artesão, sobretudo, a capacidade de imaginar para além daquilo que ele está vendo. Os vários modelos de pés torneados, de outras épocas, ainda guardados
61. Ruskin (2004, p. 106), edição em português. No original: "For I believe one of the worst symptoms of modern society to be, its notion of great inferiority, and ungentlemanliness, as necessarily belonging to the character of a tradesman. I believe tradesmen may be, ought to be - often are, more gentlemen than idle and useless people." Ruskin (1905, p. 98). 


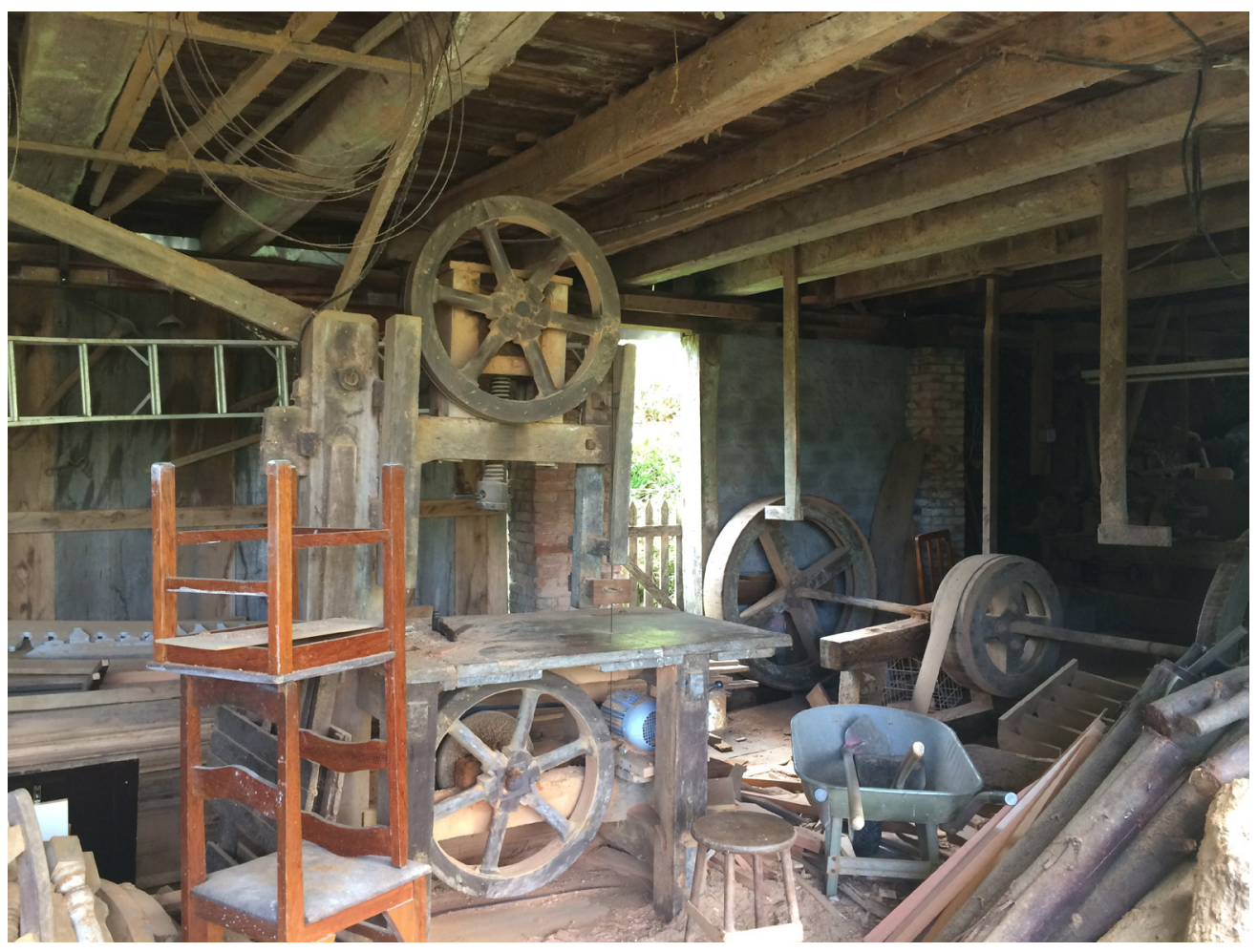

Figura 21 - Detalhe dos barrotes da área onde funcionava a serraria, 2017. Fotografia do autor.

na marcenaria, acomodados sobre os barrotes que sustentam o telhado da edificação, servem de repertório para este artífice, além de dar vida e constituir a ambiência do seu espaço de trabalho. Contudo, mesmo com tal repertório, quando a ideia da forma a ser torneada não surge em seu pensamento, o simples fato de ligar a máquina e da madeira começar a girar no torno o auxiliam no seu desempenho criativo: "às vezes, eu não sei o que fazer... então eu coloco a peça no torno e a cabeça se abre".

Ainda considerando o trabalho deste artífice, é possivel perceber que, além de uma relação corporal com a madeira, existe, também, uma relação corporal com a edificação, que manifesta-se na sua ligação com a ambiência da marcenaria. $\bigcirc$ ambiente da edificação que se forma ao abrigo da estrutura construída, o cheiro da madeira e, principalmente, a sonoridade da queda-d'água, de alguma maneira influenciaria na prática do seu ofício: "eu estou tão acostumado com aquele barulhinho que eu sinto falta". Cabe ressaltar que o trabalho de Olclésio é um trabalho solitário. E essa solidão mostra-se necessária para que a matéria igualmente se relacione com o artesão, uma vez que, mesmo nos raros momentos de trabalho conjugado, a comunhão primeira seria o encontro individual do artífice com a madeira. É uma solidão 
parcial, todavia, porquanto acompanhada pelos materiais e pelos instrumentos de trabalho, objetos de amor e de labor. Se considerarmos as diversas camadas da edificação, que serviu de corpo para as várias gerações de artífices da madeira dessa família, tal solidão se revelaria como um encontro particular, alimentado pelos laços de afeição entre o artesão e a madeira e entre o artesão e a sua história, embora isso não seja racionalmente declarado por este artífice.

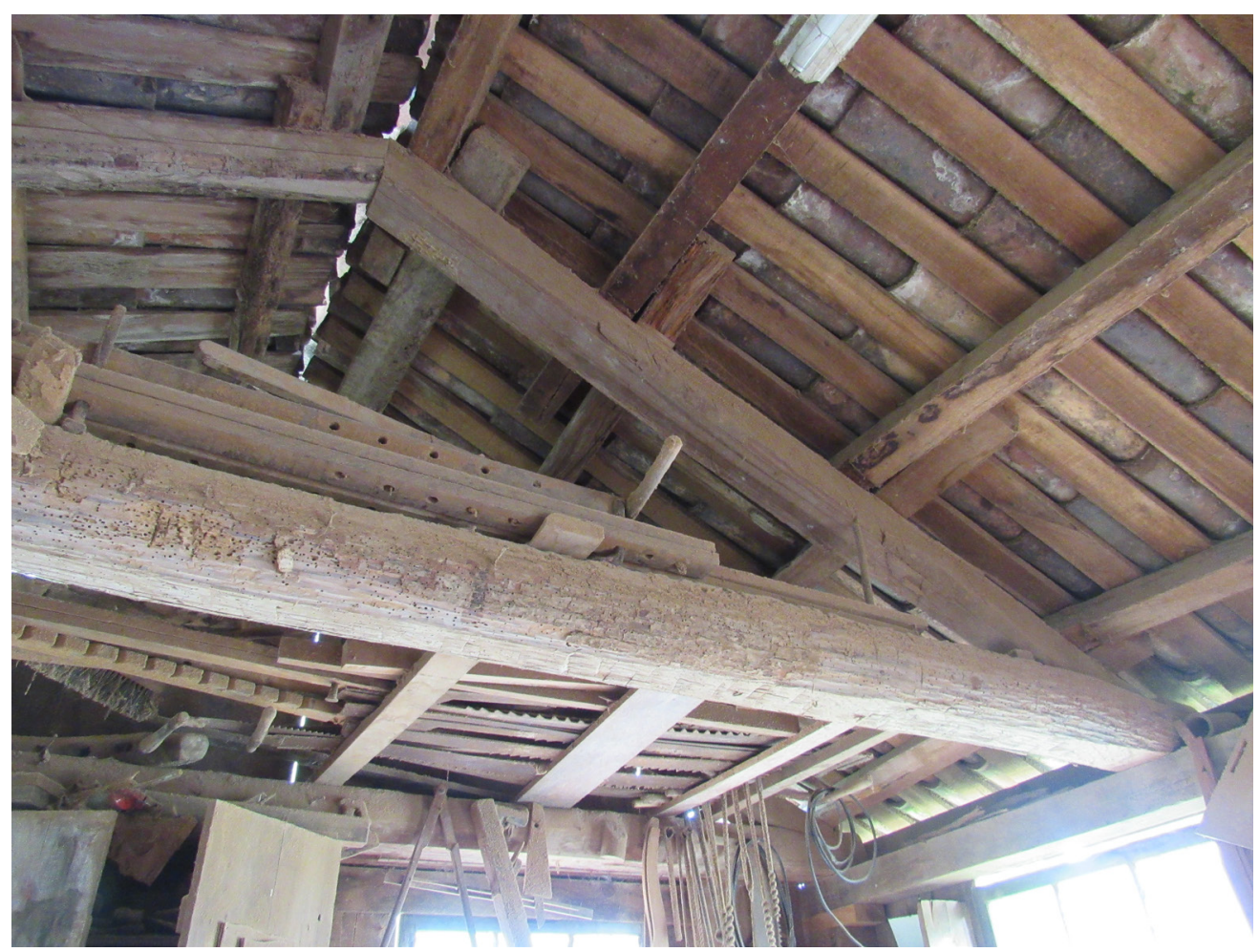

Figura 22 - Detalhe do telhado da marcenaria, 2017. Fotografia do autor.

Um pouco mais à frente do edifício da marcenaria, conservando certa distância, encontra-se a casa da família Bez Fontana, instalada numa parte mais elevada do sítio (figura 23). A construção original, feita inteiramente em madeira, é formada, de acordo com os relatos de Olclésio, por quatro espécies desse material: canela, peroba, cedro e louro. As madeiras utilizadas para a construção da casa, como era comum nas regiões colonizadas por imigrantes, foram retiradas do próprio terreno, uma vez que se fazia necessária a derrubada para a ocupação do solo. Considerando os seus longos anos de vida, a casa é constituída por várias fases, no que se refere aos seus volumes, a julgar pelas construções em alvenaria que se formam próximo ao volume principal. E, também, por várias camadas, no que se refere à preservação e à conservação de sua matéria. Nesse sentido, a 
casa revela-se, ela mesma, um corpo vivo que, da mesma forma que resguarda a construção primeira, acolhe a contribuição de cada geração da família. Entretanto, o grande e centenário volume em madeira mantém-se soberano em relação aos demais. $\bigcirc$ corpo da antiga edificação é formado por dois volumes: um maior que abriga as salas e os quartos e outro menor que, na parte superior, abriga quartos e, na inferior, forma uma área de passagem que hoje conduz à cantina e à cozinha. Os dois volumes encontram-se lado a lado e formam um conjunto separado apenas pelo desenho dos telhados de duas águas, que têm seu encontro na lateralidade da parte interna. Numa das fachadas, em que a fundação é aparente, é possível perceber que a casa foi construída sobre pedras brutas que a elevam do solo, de onde partem as peças que estruturam a edificação. $O$ tabuado de madeira, que se apoia na estrutura, não guarda uma medida constante e as irregularidades que se formam de suas variações, aliadas ao volume das matajuntas, proporcionam uma agradável diversidade nas larguras das tábuas.

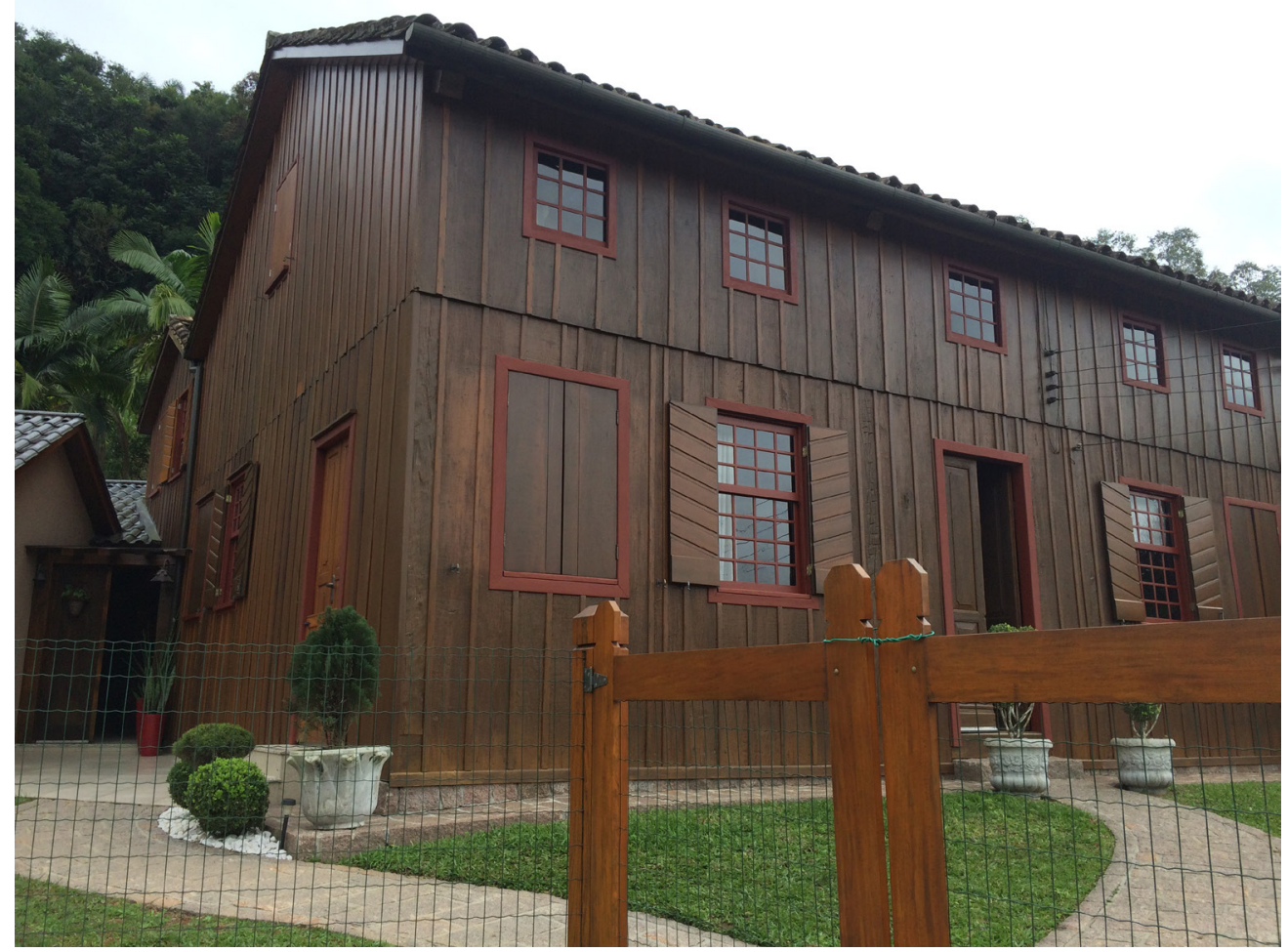

Figura 23 - Casa da família Bez Fontana, 2017. Fotografia do autor.

A parte maior da edificação é formada por dois pisos de alturas desiguais: o primeiro piso mantém-se mais alto em toda a sua extensão, enquanto o segundo piso iguala-se à altura do primeiro somente na cumeeira, utilizando-se da parte que é normalmente reservada ao sótão. A fachada que se abre para o leste é formada 
por quatro janelas e uma porta, na parte de baixo, e por cinco janelas, na parte de cima, formando uma composição simétrica, em que a localização das aberturas dos dois pisos se equivalem entre si. As aberturas do piso inferior são formadas por uma folha dupla de madeira de forma que, quando fechadas, parecem ser de folhas simples e, quando abertas, pequenos vincos em baixo relevo formam vigorosas linhas diagonais que the dão certo movimento. Além disso, janelas de caixilhos em guilhotina, com quadrícula envidraçada, finalizam o conjunto.

A casa é um generoso corpo amadeirado, não só por conta do seu tamanho, mas pela presença do volume edificado. A edificação acomoda solidariamente as várias camadas do tempo demonstradas, sobretudo, na aparência da madeira que compõe seus elementos estruturais. Algumas peças ainda guardam as particularidades dos cortes manuais, da mesma maneira que convivem com a precisão e a regularidade das peças feitas em um tempo mais recente. As irregularidades da fabricação artesanal também se mostram presentes no sistema de travamento de algumas portas do interior da casa, como pode ser observado nas tramelas feitas totalmente em madeira (figuras 28 e 29). Na parte mais alta da edificação, bem próximo da cumeeira do telhado, é possivel perceber o corte igualmente artesanal no encaixe das terças, além da colocação das telhas que se observa entre os caibros (figuras 25 e 26). Dentro da casa, a sinceridade construtiva e a verdade executiva do artífice construtor se manifestam, principalmente, na preservação da cor original da madeira. Talvez pelo fato do ofício com a madeira estar presente por tantas gerações é possível perceber uma intensa relação com essa materialidade que se revela não somente no saberfazer do artesão, mas também em toda a família que convive com as edificações e com o entorno do sítio. Essa relação de proximidade com o material faz com que a madeira, por vezes, se torne, ela mesma, uma presença fraterna. Como uma companhia presente desde muito tempo, o respeito por sua natureza material talvez se justifique porque não se quer que tal companhia seja outra coisa além dela mesma - a madeira (figuras 24 e 25). Assim, as diversas tonalidades de sua cor natural, os desenhos que se formam dos seus veios, a luz que entra pela janela e que perde força ao encontrar o grande volume amadeirado, a sonoridade que se mostra quando se caminha sobre o tabuado nos mantêm diante, permanentemente, da presença viva desse material. A casa é somente o que ela revela ser - uma engenhosa estrutura de madeira em que o artesão soube retirar da matéria o alimento para a sua edificação. A honestidade construtiva fica muito evidente nas moradias rurais construídas pelos imigrantes, sobretudo nas edificações em madeira - se considerarmos a simplicidade de suas linhas e de suas formas. Embora também representem as condições de trabalho que conduziram a sua construção naquela 
62. Ruskin (1903, p. 54-60).

63. Ruskin (1992, p. 125). época, as edificações rurais, em madeira, evidenciam uma verdade executiva que constitui a linguagem do artífice que lida com esse material. Ao manter a natureza da madeira e ao demonstrar as integridades estruturais de sua edificação, o próprio artífice acabava, também, por inscrever, naquela materialidade, a comunhão do seu trabalho e do seu pensamento, tanto quanto daqueles que ajudaram em sua construção. Segundo Ruskin, a intenção primeira de uma obra arquitetônica deveria ser a sua ligação com a verdade, e uma das principais causas da imoralidade na arquitetura moderna residiria, justamente, na falsidade de sua natureza material, na tentativa de parecer ser aquilo que não é. Para o autor, dentre as virtudes do homem, a verdade seria aquela que mais sofria as consequências do comportamento moderno por não admitir gradações. "Mentiras bem-intencionadas", "leves e acidentais", pequenos delitos morais que, misturados aos atos cotidianos, tornavam-se despercebidos ou justificáveis. Tais delitos colaboravam diretamente para a corrupção das relações e das ações do homem e, consequentemente, para o desvirtuamento de suas práticas artísticas. Segundo o autor, o arquiteto poderia não conseguir alcançar a beleza, a formosura, o poder ou a inventividade em sua obra, mas ele teria a obrigação moral de se guiar pela verdade e produzir uma arquitetura honesta. ${ }^{62}$

Ainda considerando a verdade nas práticas artísticas, Ruskin declarava que, mesmo mantendo-se a comunhão entre trabalho e pensamento, o ofício dele resultante também poderia levar à corrupção, se a verdade executiva não fosse revelada. $\bigcirc$ autor compara o trabalho de um tecelão e de um pintor de paredes que imita o mármore. No primeiro, apesar do tecelão executar um trabalho sobretudo mecânico, existiria certa liberdade de espírito e de pensamento entre o vai e vem das linhas. Já no segundo, apesar do pensamento estar aliado ao fazer do pintor, ao intentar falsear uma superfície, o resultado do seu trabalho seria apenas uma materialidade vil, porque decorrente de um trabalho nulo - embora tal trabalho exigisse grande habilidade do artesão. ${ }^{63}$

Tomando o trabalho expressivo do homem, principalmente aquele realizado na arquitetura, Ruskin dizia, também, que haveria uma relação entre a presença da alma humana na criação material e o "estado ativo e dormente da matéria" e que seria justamente a plenitude de vida manifestada na coisa produzida que the conferia maior ou menor valor. Considerando as energias que animam a vida do homem, este seria a única criatura que possuía uma vida dupla - além de uma vida corporal, uma vida mental e intelectual. Por isso, somente o homem poderia usar a sua energia igualmente de forma dupla expressando uma "vida verdadeira" e uma "vida falsa". A vida verdadeira seria uma força capaz de organizar e governar as coisas externas a fim de obter delas alimento e instrumento, mas que não 


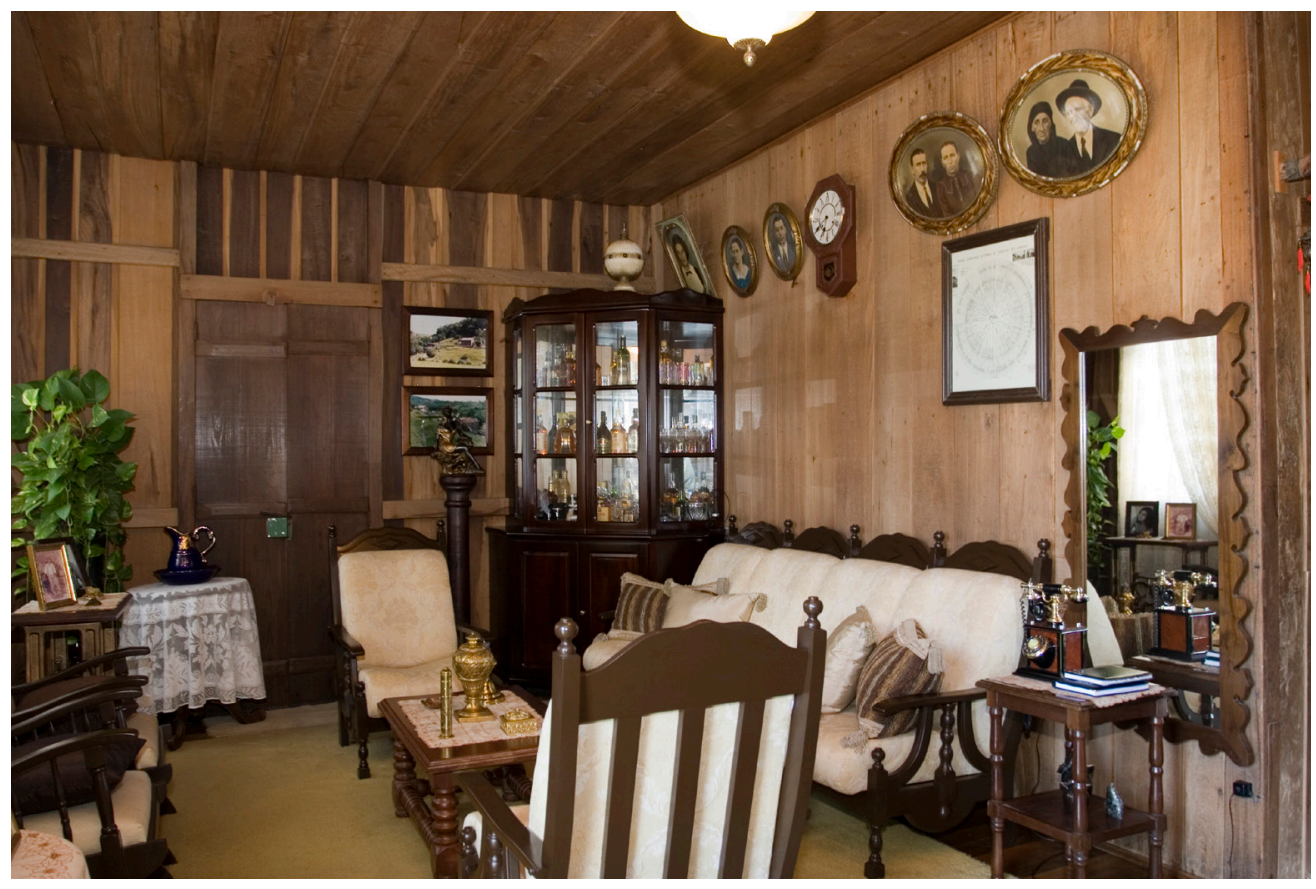

Figura 24 - Interior da casa da família [a], 2005. Foto: IPHAN/SC; Tempo Editorial.

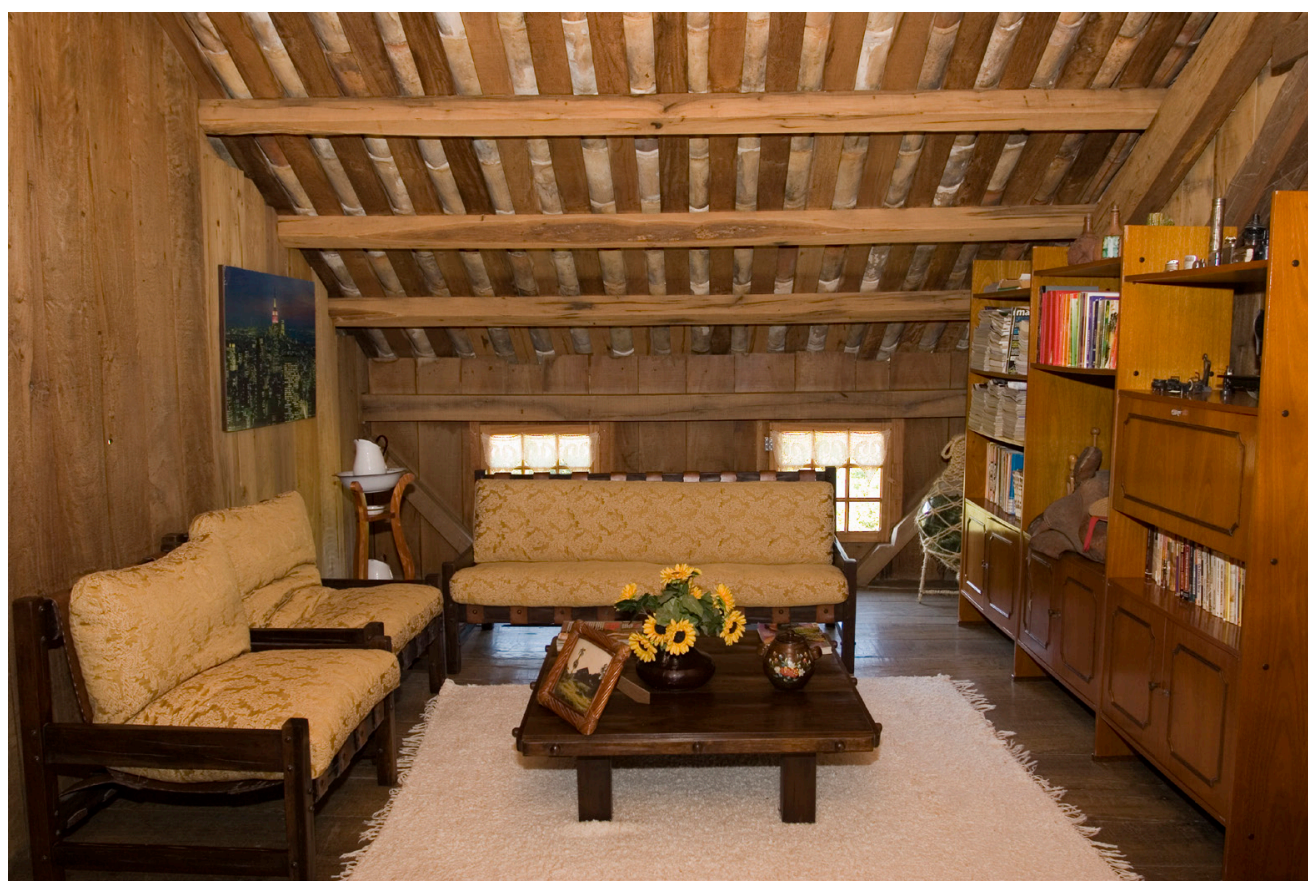

Figura 25 - Interior da casa da família [b], 2005. Foto: IPHAN/SC; Tempo Editorial. 
64. Ruskin (1903, p. 190195)

65. Ruskin (1903, p. 200, tradução nossa). No original: "[...] accidental carelessnesses of measurement or of execution being mingled undistinguishably with the purposed departures from symmetrical regularity".

66. Ruskin (1903, p. 199 , tradução nossa). No original: "[...] the vigour of a true school of early architecture, which is either working under the influence of high example or which is itself in a state of rapid development, is very curiously traceable, among other signs, in the contempt of exact symmetry and measurement, which in dead architecture are the most painful necessities".

67. Ruskin (1903, p. 214). deixaria de ouvir, com humildade e obediência, a inteligência superior. Entretanto, tal obediência seria como uma escolha voluntária em que o homem não perderia a sua própria autoridade como princípio de julgamento. A vida falsa seria uma vida de ação amortecida, uma vida sem pensamento, sem intelecto e sem moral, regida pelas coisas externas, em que o homem, em vez de florescer, cristalizava-se, fazendo as coisas meramente por fazer. E de todas as naturezas da arte, a arquitetura seria aquela que mais sofria pelos danos provocados por uma alma dormente, porque ela dependeria, mais sensivelmente, do "calor da vida verdadeira" de todos aqueles que trabalharam em sua edificação. ${ }^{64} \mathrm{~A}$ arquitetura, enquanto corpo vivo, carregaria, em sua materialidade, os registros tanto da alma dormente quanto da alma animada de seus trabalhadores manifestados, sobretudo nas mudanças e variações declaradas no desenho do edifício; certas "negligências acidentais de medição ou de execução", misturadas aos "desvios pretendidos de uma regularidade simétrica", ${ }^{65}$ inscreveriam no corpo edificado o gesto vivo de cada trabalhador. Para Ruskin, o "[...] vigor de uma verdadeira escola de arquitetura primitiva" estaria, entre outros vestígios, "no desprezo da exata simetria e medição, que nas arquiteturas mortas são as necessidades mais dolorosas". 660 bom trabalho na arquitetura, segundo ele, seria o trabalho manual livre, em que mente e coração caminhariam juntos com o saber-fazer do homem. $\bigcirc$ trabalho resultante da frieza de uma mão sem vida ou de uma mente entorpecida seria como os versos de uma poesia que, em vez de serem bem lidos e profundamente sentidos, fossem decorados para uma declamação mecanizada. ${ }^{67}$

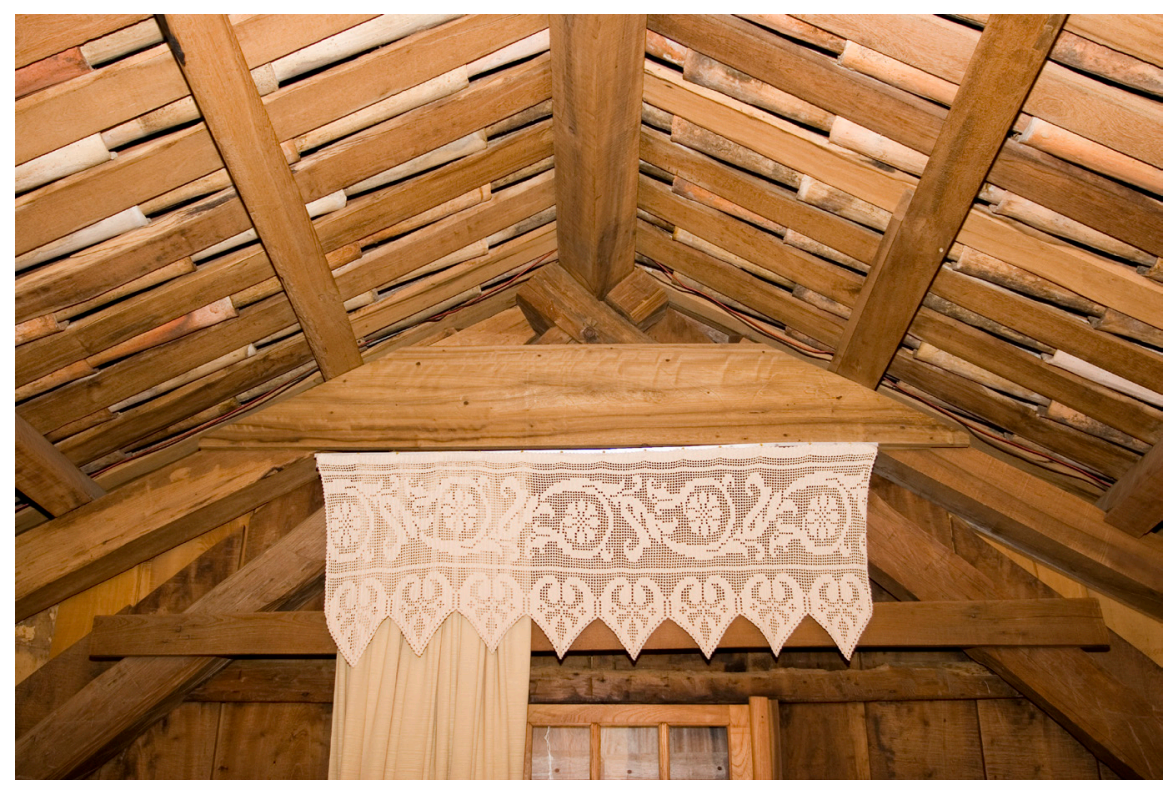

Figura 26 - Interior da casa da família [c], 2005. Foto: IPHAN/SC; Tempo Editorial. 
Discorrendo ainda sobre as variações no corpo arquitetônico, Ruskin declarava que a natureza da arquitetura gótica era constituída por tal variedade e que seriam justamente as possibilidades de mudanças que the confeririam, paradoxalmente, certa racionalidade no fazer arquitetônico. A arquitetura gótica, por ser "a única arquitetura racional", possibilitava, por meio de seus elementos formais, certas mudanças no desenho do edifício em função de algumas necessidades práticas, ajustando-se, com maior facilidade, tanto aos "serviços nobres quanto aos vulgares". Uma das virtudes dos construtores góticos teria sido, segundo Ruskin, não permitir que as ideias de simetria exterior ou de conformidade interferissem no efetivo "uso e valor" daquilo que faziam, pois entendiam que certas irregularidades no "convencionalismo estabelecido" acrescentariam interesse à simetria, em vez de prejudicá-la. Entretanto, as variações sentidas, tanto no trabalho do arquiteto quanto no trabalho do homem comum, deveriam ser resguardadas por certa dose de temperança. ${ }^{68}$

A arquitetura, assim edificada, e que constitui o cerne do fantástico paradoxo, seria para Ruskin o trabalho de uma criatura viva inteira, corpo e alma, sobretudo alma, pois a arte, não importa a sua natureza, deveria ser a "expressão de uma alma falando com outra" e a sua grandeza dependeria da preciosidade daquele que a profere. E o trabalho da alma, orientado pelos poderes superiores, seria o trabalho que procede de um "coração ativo", aperfeiçoado pelo intelecto e tratado pelas mãos do homem. ${ }^{69} \bigcirc$ fantástico paradoxo da imperfeição, que orienta e fundamenta a estética ruskiniana, resguarda o fazer humano nas práticas artísticas, sobretudo na arquitetura. E, na mesma medida em que se reclama a presença inteira do artista e do artífice no trabalho de execução do corpo arquitetônico, caberia aos que fossem desfrutar daquela materialidade também entregar-se por inteiro. Esta seria a única condição, segundo ele, de nos encontrarmos e de nos conhecermos verdadeiramente.

A apropriação do pensamento ruskiniano para analisar tanto as edificações em madeira da propriedade Bez Fontana quanto o ofício da marcenaria nos permite iluminar outras formas de ver e de pensar tais manifestações. Se Ruskin utiliza as edificações góticas como corpo de trabalho para analisar a manifestação do fantástico paradoxo da imperfeição, quando pensamos nas edificações rurais estas podem parecer, num primeiro momento, distantes de tais expressões. Assim como a arquitetura gótica, segundo o autor, evidenciava a inseparável ligação entre as formas externas e a energia que animava seus artesãos, as edificações da família Bez Fontana parecem expressar, em sua materialidade, tanto a necessidade e a utilidade de sua construção quanto a vida e o trabalho dos artífices nela
68. Ruskin (1904, v. II, p. 204-215).

69. Ruskin (1904, v. III, p. 196-230). 
Figura 27 - Móvel feito por Sebastião, 2005. Foto: IPHAN/SC; Tempo Editorial.
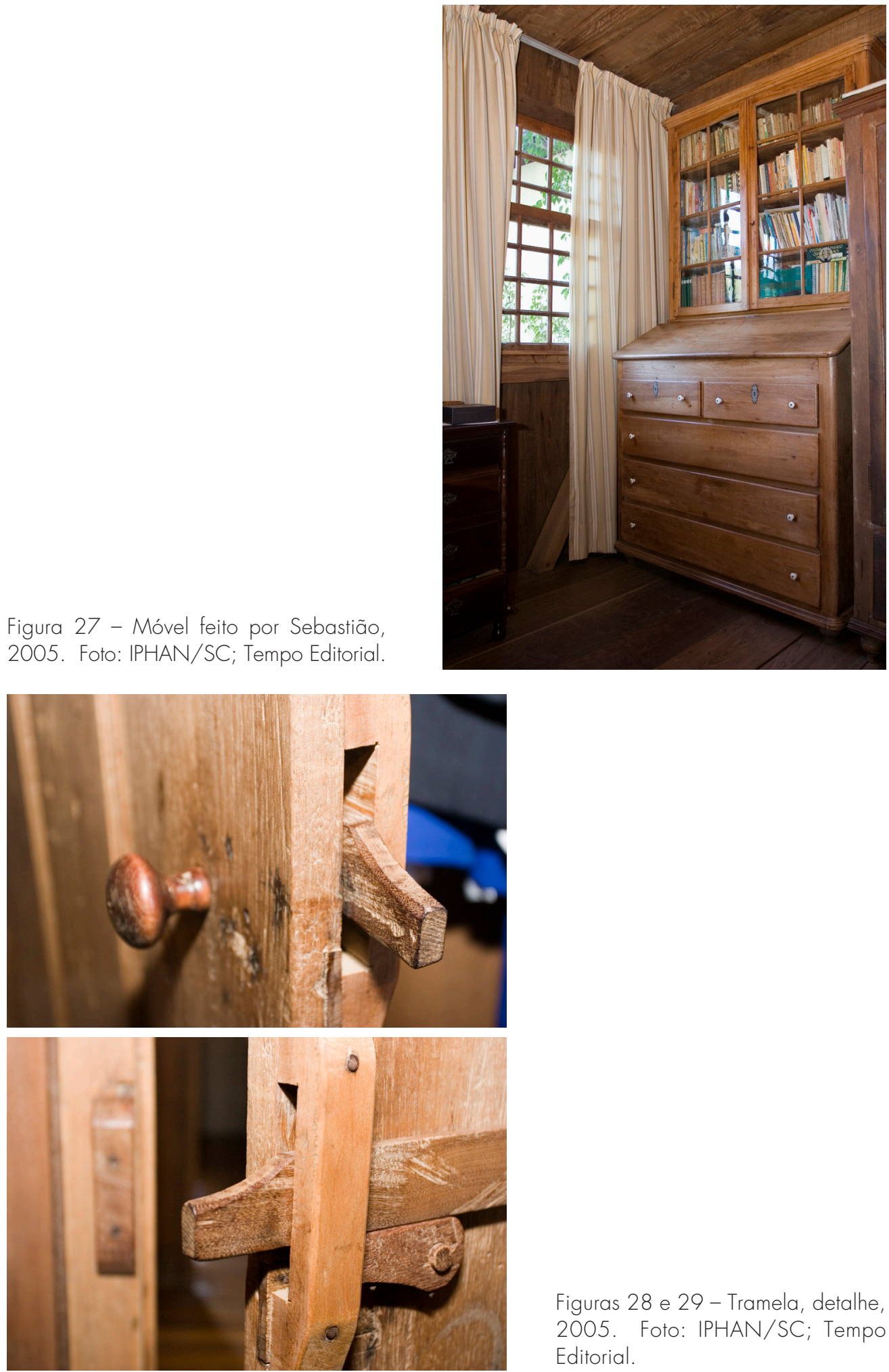

Figuras 28 e 29 - Tramela, detalhe, 2005. Foto: IPHAN/SC; Tempo Editorial. 
envolvidos. Mais do que procurar similitudes e semelhanças entre a "expressão formal" e a "expressão mental" dessas manifestações arquitetônicas, a apropriação das concepções ruskinianas, sobretudo o fantástico paradoxo da imperfeição, nos possibilita olhar para a arquitetura rural pelo viés de sua força produtiva, ${ }^{70}$ do trabalho humano necessário à sua edificação - presente em sua materialidade por meio do ofício de artesãos. Como corpo de trabalho para os primeiros artífices imigrantes, as edificações rurais resguardadas formam, com seu entorno natural, uma paisagem arquitetônica singular e testemunham a artesania dos ofícios construtivos tradicionais, da mesma maneira que ainda animam o trabalho das novas gerações.

Além disso, analisar o trabalho do artífice pelo fantástico paradoxo ruskiniano, seja do artesão imigrante que edificou a sua moradia e contribuiu para a expressão da arquitetura rural catarinense, seja daqueles artesãos que ainda praticam um ofício fundamentado nos saberes tradicionais, também nos permite compreender melhor a potência que se manifesta no gesto do artífice e em seus modos de saber-fazer. No conjunto Bez Fontana, esse gesto tanto se manifesta na materialidade das primeiras edificações quanto se mostra nas gerações que se seguiram. Os artesãos dessa família, animados, sobretudo, pela expressão dos primeiros artífices, contribuíram e ainda contribuem com seu trabalho, ao mesmo tempo em que guardam, na materialidade mesma, a presença dos demais artesãos. É possível perceber um respeito, tanto pelas edificações quanto pelos saberes artesanais ainda preservados, como aquele que se tem diante de uma pessoa mais velha. Entretanto, é possível perceber, também, que, apesar do respeito revelado, tanto as edificações quanto a artesania resguardada pelos artífices da família vão recebendo os acréscimos de outras épocas. Dessa forma, passado e presente não estão aqui separados em territórios distintos, mas convivem fraternalmente, e essa convivência, de alguma maneira, também anima a matéria que ainda permanece. Pois, da mesma forma que a família Bez Fontana reconhece e conserva a sua história inicial, tece com ela novos alinhavos.
70. As relações de trabalho no processo produtivo da arquitetura, analisadas sob as concepções do pensamento ruskiniano, podem ser observadas na publicação Sérgio Ferro $e$ John Ruskin: crítica ao processo produtivo da arquitetura. Cf. Amaral; Guerini Filho (2017). O fazer artesanal, a produção industrializada e suas relações com o trabalho da arquitetura, igualmente analisadas sob as concepções do pensamento ruskiniano, podem ser observadas na publicação "Ruskin e o trabalho da arquitetura". Cf. Lira (2006). 


\section{REFERÊNCIAS}

LIVROS, ARTIGOS E TESES

AMARAL Cláudio Silveira; GUERINI FILHO, Régis Alberto. Sérgio Ferro e John Ruskin: crítica ao processo produtivo da arquitetura. Revista Arquitextos (online), ano 17, março de 2017.

CLARK, Kenneth. The Gothic Revival: an Essay in the History of Taste. London: Constable, 1950.

CLARK, Kenneth. Ruskin Today. Baltimore: Penguin Books, 1967.

D’AGOSTINO, Mário Henrique Simão; PINHEIRO, Maria Lucia Bressan. A noção de pitoresco no debate cultural das primeiras décadas do século XX no Brasil. Desígnio - Revista de História da Arquitetura e do Urbanismo, Faculdade de Arquitetura e Urbanismo, Universidade de São Paulo, São Paulo: Annablume, n.1, março, 2004, p. 119-128.

DALL'ALBA, João Leonir. Imigrantes italianos em Santa Catarina. In: DE BONI, Luis Alberto (org). A presença italiana no Brasil. Porto Alegre: EST, 1987.

DALL'ALBA, João Leonir. Imigração italiana em Santa Catarina. Caxias do Sul: EDUCS; Porto Alegre: EST; Florianópolis: Lunardelli, 1983.

FERREIRA, Luís Fernando Vieira. Azambuja e Urussanga. Niterói: Oficinas Gráficas, 1939.

FONTANA, Germano Bez. História de minha vida: memórias, imigração e outros fatos. Florianópolis: Agnus, 1998.

FRAMPTON, Kenneth. História crítica da arquitetura moderna. Tradução de Jefferson Luiz Camargo e Marcelo Brandão Cipolla. São Paulo: Martins Fontes, 2015.

GAMA, Ruy. História da técnica e da tecnologia. São Paulo: TAQ/ Edusp, 1985.

IPHAN. Roteiros nacionais de imigração Santa Catarina - Dossiê de Tombamento: histórico, análise e mapeamento das regiões. VIEIRA FILHO, Dalmo; WEISSHEIMER, Regina M. (coords.), v. I. Florianópolis: $11^{\mathrm{a}}$ Superintendência Regional IPHAN/Santa Catarina, [s. d.]a. 
IPHAN. Roteiros nacionais de imigração Santa Catarina - Dossiê de Tombamento: síntese tombamentos federais. VIEIRA FILHO, Dalmo; WEISSHEIMER, Regina M. (coords.), v. II. Florianópolis: $11^{\mathrm{a}}$ Superintendência Regional IPHAN/Santa Catarina, $[s . d$.]b.

IPHAN. Mestres artífices Santa Catarina: cadernos de memória. PIMENTA, Margareth de Castro Afeche (coord.). Brasília: IPHAN, 2012.

KATINSKY, Júlio Roberto. Glossário dos carpinteiros de moinho. In: GAMA, Ruy (org). História da técnica e da tecnologia. São Paulo: TAQ/Edusp, 1985. p. 216-242.

LANDOW, George. Aesthetic and Critical Theory of John Ruskin. Princeton: Princeton University Press, 1971.

LIRA, José Tavares Correia. Ruskin e o trabalho da arquitetura. Risco: Revista de Pesquisa em Arquitetura e Urbanismo, Universidade de São Paulo, São Paulo, v. 4, n. 2, p. 77-86, 2006.

MARZANO, Luigi. Colonos e missionários italianos na floresta do Brasil. Tradução de João Leonir Dall'Alba. Florianópolis: UFSC, 1985.

MATTOS, Jacintho Antonio. Colonisação do estado de Santa Catharina: dados históricos e estatísticos (1640-1916). Florianópolis: O Dia, 1917.

PINHEIRO, Maria Lucia Bressan. John Ruskin e as sete lâmpadas da arquitetura - algumas repercussões no Brasil. In: RUSKIN, John. A Lâmpada da memória (apresentação). Tradução: Maria Lucia Bressan Pinheiro. $2^{\text {a }}$ ed. Cotia: Ateliê Editorial, 2013. p. 9-48.

POSENATO, Júlio. Arquitetura da imigração italiana no Rio Grande do Sul. Porto Alegre: EST/EDUCS, 1983. v. 4.

RUSKIN, John. A Lâmpada da memória. Tradução: Maria Lucia Bressan Pinheiro. Cotia: Ateliê Editorial, 2013.

RUSKIN, John. A economia política da arte. Tradução: Rafael Cardoso. Rio de Janeiro: Record, 2004.

RUSKIN, John. As pedras de Veneza. Tradução: Luís Eduardo de Lima Brandão. São Paulo: Martins Fontes, 1992. 
RUSKIN, John. John Ruskin. Selvatiqueza (excerto de A Natureza do Gótico). Tradução: José Tavares Correia de Lira. Risco: Revista de Pesquisa em Arquitetura e Urbanismo, Universidade de São Paulo, São Paulo, v. 4, n. 2, p. 67-76, 2006.

RUSKIN, John. The Seven Lamps of Architecture. London: Library Edition, works, v. viii, 1903. Disponível em: <https://bit.ly/2nVdW45>.

RUSKIN, John. The Stones of Venice. London: Library Edition, v. I, works, v. ix, 1903 Disponível em: <https://bit.ly/2nVdW45>.

RUSKIN, John. The Stones of Venice. London: Library Edition, v. II, works, v. x, 1904 Disponível em: <https://bit.ly/2nVdW45>.

RUSKIN, John. The Stones of Venice. London: Library Edition, v. III, works, v. xi, 1904 Disponível em: <https://bit.ly/2nVdW45>.

RUSKIN, John. Two Lectures on the Political Economy of Art (1857-1880). In: RUSKIN, John. A Joy for ever. London: Library Edition, part I, works, v. xvi, 1905, p. 15-174. Disponível em: $<$ https://bit.ly/2nVdW45>.

RUSKIN, John. Inaugural Address at the Cambridge School of Art (1858). In: RUSKIN, John. A Joy for ever. London: Library Edition, part II, works, v. xvi, 1905, p. 177-201. Disponível em: $<$ https://bit.ly/2nVdW45>.

RUSKIN, John. Modern Manufacture and Design (1859). In: RUSKIN, John. The Two Paths. London: Library Edition, lecture III, works, v. xvi, 1905, p. 319-345. Disponível em: <https:// bit.ly/2nVdW45>.

RUSKIN, John. Influence of Imagination in Architecture (1857). In: RUSKIN, John. The Two Paths. London: Library Edition, lecture IV, works, v. xvi, 1905, p. 346 -374. Disponível em: https://bit.ly/2nVdW45>.

RUSKIN, John. Unto this Last (1860). London: Library Edition, part I, works, v. xvii, 1905, p. 5-118. Disponível em: <https://bit.ly/2nVdW45>.

SEYFERTH, Giralda. Imigração e cultura no Brasil. Brasília: UnB, 1990.

TOWNSEND, Francis G. Ruskin and the Landscape Feeling: a critical analysis of his thought during the crucial years of his life, 1843-56. Urbana: University of Illinois, 1951. 
WEIMER, Günter. Arquitetura Popular Brasileira. 2a ed. São Paulo: Martins Fontes, 2012.

Entrevista

FONTANA, Olclésio Bez. Entrevista concedida em sua residência, na cidade de Urussanga, nos dias 20 fev. 2017 e 18 maio 2017.

Artigo apresentado em 12/10/2018. Aprovado em 18/6/2019.

\section{(cc) BY}

All the contents of this journal, except where otherwise noted, is licensed under a Creative Commons Attribution License 